\title{
The establishment of parenthood
}

Citation for published version (APA):

Forder, C., \& Saarloos, K. (2007). The establishment of parenthood: A story of successful convergence? (1 ed.) Faculty of Law, Universiteit Maastricht. Maastricht Faculty of Law Working Papers Vol. 2007 No. 1

Document status and date:

Published: 01/02/2007

Document Version:

Publisher's PDF, also known as Version of record

\section{Please check the document version of this publication:}

- A submitted manuscript is the version of the article upon submission and before peer-review. There can be important differences between the submitted version and the official published version of record.

People interested in the research are advised to contact the author for the final version of the publication, or visit the DOI to the publisher's website.

- The final author version and the galley proof are versions of the publication after peer review.

- The final published version features the final layout of the paper including the volume, issue and page numbers.

Link to publication

\footnotetext{
General rights rights.

- You may freely distribute the URL identifying the publication in the public portal. please follow below link for the End User Agreement:

www.umlib.nl/taverne-license

Take down policy

If you believe that this document breaches copyright please contact us at:

repository@maastrichtuniversity.nl

providing details and we will investigate your claim.
}

Copyright and moral rights for the publications made accessible in the public portal are retained by the authors and/or other copyright owners and it is a condition of accessing publications that users recognise and abide by the legal requirements associated with these

- Users may download and print one copy of any publication from the public portal for the purpose of private study or research.

- You may not further distribute the material or use it for any profit-making activity or commercial gain

If the publication is distributed under the terms of Article $25 \mathrm{fa}$ of the Dutch Copyright Act, indicated by the "Taverne" license above, 


\section{Maastricht Working Papers Faculty of Law}

\section{The establishment of parenthood}

A story of successful convergence?

Caroline Forder and Kees Saarloos

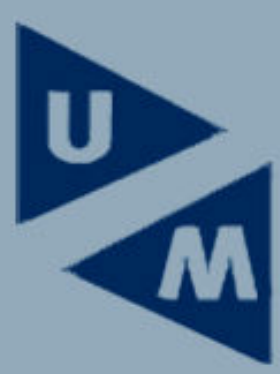

2007-01 
All rights reserved.

No part of this paper may be reproduced in any form without the permission of the author(s).

This Working Paper series from the Faculty of Law, University of Maastricht, aims to further excellence in scholarship. It allows Maastricht-based authors to bring their work-in-progress to a wide audience, facilitating fruitful discussion and critical input on nascent ideas and projects to the benefit of both author and reader. To this end, readers are encouraged to treat the series as interactive and to contact authors with their comments.

Those wishing to submit papers for consideration are invited to send work to working.papers@law.unimaas.nl.

Our submission guidelines and further information are available at $\mathrm{http} / / / \mathrm{www}$.unimaas.nl/maastrichtworkingpapers

(C) Caroline Forder and Kees Saarloos

Published in Maastricht, February 2007

\author{
Faculty of Law \\ Universiteit Maastricht \\ Postbox 616 \\ $6200 \mathrm{MD}$ \\ Maastricht \\ The Netherlands
}

Author email: Caroline.Forder@ua.ac.be; k.saarloos@pr.unimaas.nl

This paper is to be cited as Maastricht Faculty of Law Working Paper 2007/1 


\section{The establishment of parenthood: a story of successful convergence? Prof.dr. Caroline Forder ${ }^{1} \&$ mr.iur. Kees Saarloos ${ }^{2}$}

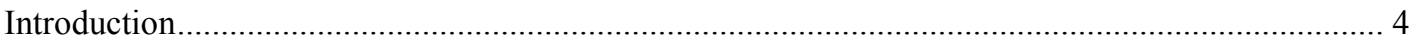

1. National laws on legal affiliation: how do they differ? ........................................................ 5

1.1 A model for the comparison on national laws on legal affiliation ......................................... 5

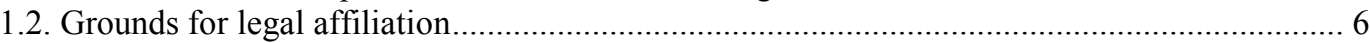

1.2.1. Grounds for legal maternity .............................................................................. 7

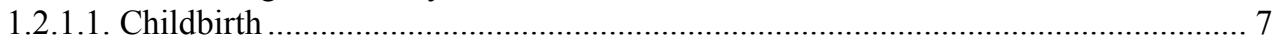

1.2.1.2. Apparent status or possession d'état …………………………………………....... 9

1.2.1.3. The relationship between genetic affiliation and apparent status under French law

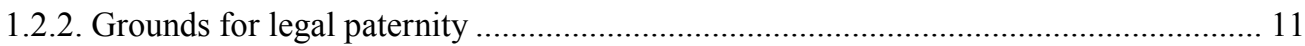

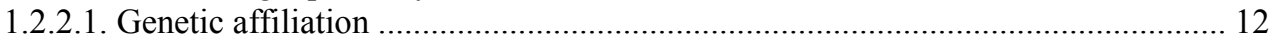

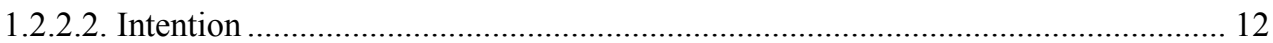

a. Definition of the field of application of intention as a ground for legal affiliation ......... 15

b. Differences between national provisions on the consequences of assisted reproduction 17

1.2.3. Grounds for legal parenthood - overview ................................................................ 21

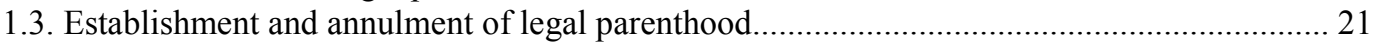

1.3.1. Establishment of parenthood - four methods ........................................................... 22

1.3.1.1. Ex lege existence of parenthood....................................................................... 22

1.3.1.2. Establishment of parenthood by means of administrative action .......................... 28

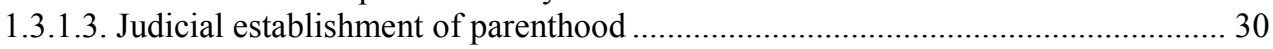

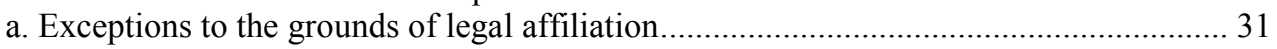

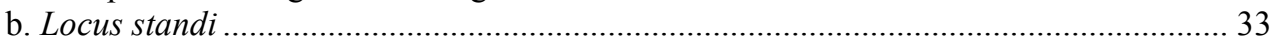

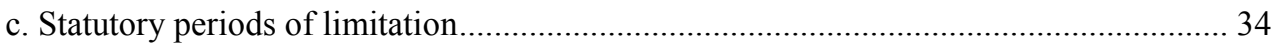

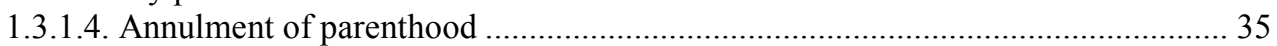

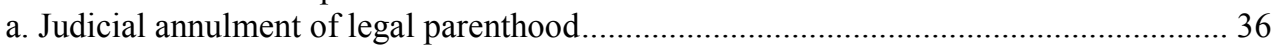

b. Restrictions on judicial annulment of paternity under Dutch law ................................. 37

c. Judicial annulment of legal parenthood and apparent status .......................................... 38

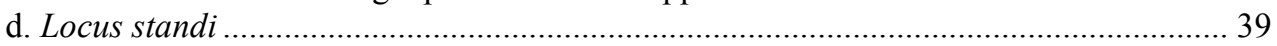

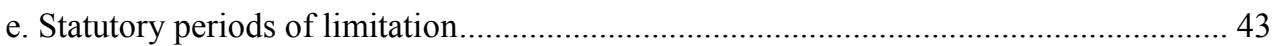

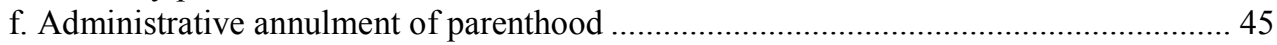

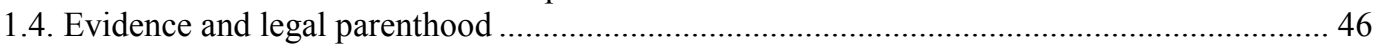

1.4.1. Evidence and ex lege existence of parenthood........................................................ 47

1.4.2. DNA evidence in court proceedings on (legal) affiliation ......................................... 50

2. The European Court of Human Rights and national laws of parenthood........................................ 56

2.1. Parenthood: natural reproduction and assisted reproduction................................................. 57

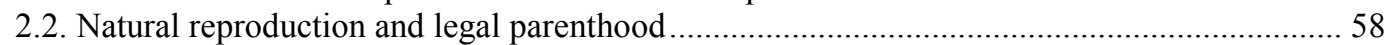

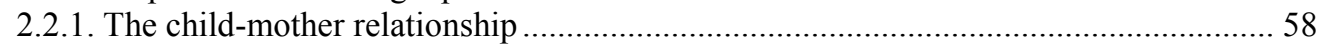

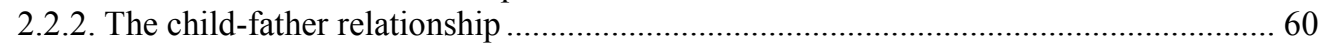

2.2.2.1. The presence or absence of a biological link between the man and the child....... 60

2.2.2.2. The social relationship between the mother and father or between the father and

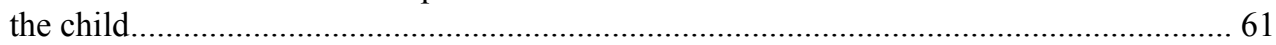

2.2.2.3. Presence or absence of a conflict of interest regarding the establishment of

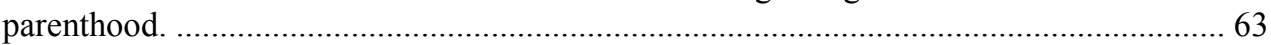

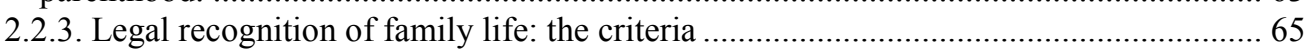

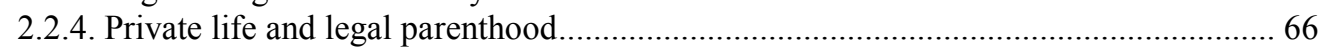

2.2.5. The significance of the European Court's attention for the presence or absence of a

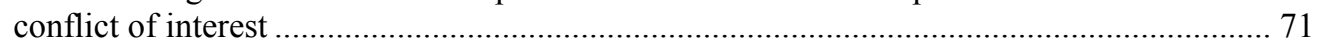

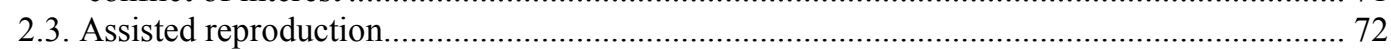

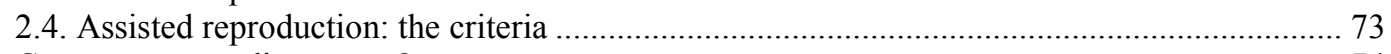

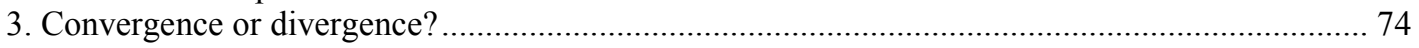

\footnotetext{
${ }^{1}$ University of Antwerp, Belgium.

${ }^{2}$ University of Maastricht, the Netherlands.
} 


\section{Introduction}

The law on legal affiliation or parentage determines who the legal parents of a child are and/or how legal parenthood is established and annulled. The law on legal affiliation does not deal with the consequences of the existence of legal affiliation, such as parental responsibility, inheritance and maintenance. Together with the law on marriage, the law on legal affiliation is at the heart of family law in European legal systems, since broadly speaking, marriage and affiliation define the legal family.

Since the national rules on legal affiliation influence the family life of the individuals involved, they have to withstand the scrutiny of Article 8 European Convention of Human Rights (hereafter: ECHR) which guarantees the respect for private and family life. In the field of legal affiliation, landmark cases of the European Court of Human Rights (hereafter: the European Court) on Article 8 ECHR, like Marckx ${ }^{3}$ and Keegan, ${ }^{4}$ are generally understood to have had a converging effect on the law on legal affiliation in Europe. In this paper we will explore exactly in which matters the European Court has been active and to what extent the European Court's case law leaves room for divergent national laws on legal affiliation.

Our starting-point is the assumption that in order to determine the harmonising effect of the case law of the European Court, one has to analyse to what extent the supranational legal order, in this case Article $8 \mathrm{ECHR}$ as interpreted by the European Court, allows for differences among the national legal systems. The degree of convergence of national laws on legal affiliation is determined by the leeway for which the legal order of the ECHR allows. In order to examine this leeway we will first analyse the differences between national laws regarding legal affiliation. This will involve setting out the whole scope of the law of affiliation. After that, it will be examined which parts of the national laws on legal affiliation are affected by the European Court's case law and which parts are not. In the third part, a conclusion will be drawn regarding the tendency in the law on legal affiliation towards harmonisation or divergence.

\footnotetext{
${ }^{3}$ Marckx v Belgium, Eur. Court H.R., 13th June 1979, Series A no. 31.

${ }^{4}$ Keegan v Ireland, Eur. Court H. R., 26th May 1995, Series A no. 291.
} 


\section{National laws on legal affiliation: how do they differ?}

\subsection{A model for the comparison on national laws on legal affiliation}

In this part it will be examined how the national laws on legal affiliation differ in relation to each other. It is submitted on the basis of a study of the national laws on legal affiliation in England \& Wales, France, Germany, the Netherlands and Sweden, that the national legal systems in Europe can be analysed with a general model which consists of three layers. The three layers represent the steps a hypothetical legislator would have to take were it to legislate for the first time on the question of legal parenthood. First of all, the hypothetical legislator would have to ask who, in the abstract, should be the parents of the child. At this stage, the ground for legal affiliation is formulated. The reply to the question would probably be something like: in case of natural reproduction the child ideally should be affiliated with his or her genetic parents but some interests might require that in a concrete case that this is not the case. The formulation of these interests is the second step. The interests are reflected in the system of establishment and annulment of legal parenthood. Therefore, the second stage is concerned with establishment and annulment of legal parenthood. If the hypothetical legislator has determined the starting-point for a regulation on legal affiliation and if it has determined the interests which, in a concrete case, allow for a deviation from that starting-point, the legislator has to come up with a system to translate the legal reality into tangible evidence, which will probably be a piece of paper (birth certificate, instrument of civil status, judgement and so on) explaining the legal situation. Hence, the third step our hypothetical legislator would have to take is to come up with a system for providing evidence of legal parenthood.

Based on these steps, the first layer of the model is the starting-point or ground which a national legislator has taken in its national law on legal affiliation. It will be explained below that most national legal systems have two or three grounds for legal affiliation which apply in carefully-defined circumstances. The second layer is the establishment and the annulment of legal affiliation in a concrete case. It will be explained that there are various methods to establish legal parenthood and that some of these methods allow for a certain possibility that legal parenthood is not established in conformity with the starting-point for legal affiliation in a national legal system. This result can, in certain circumstances, be remedied by an action for annulment of 
parenthood. The extent to which the mode of establishment of legal parenthood together with the action for annulment of legal parenthood allow for a deviation from the starting-point in a national legal system, reveals the additional interests which the legislature chooses to honour. The legislature can choose to honour public interests such as stability of personal status or the preservation of the traditional family and private interests such as the child's interests or the biological or social parents' interest. The third layer concerns the system of evidence of (legal) affiliation in and out of court. 'Legal' is put between brackets here, because it will be shown that, depending on the relationship between the first and the second layer in a national legal system, one may or may not have to prove legal affiliation or some other kind of affiliation (e.g. genetic affiliation).

In the following section, the model will be explained separately for legal maternity and legal paternity. Legal paternity should be understood broadly as the second parent additional to the mother, since for example in Sweden the lesbian partner of the mother can become the child's second mother by means of the Swedish rules on legal affiliation.

It is submitted that the difference between legal systems at the first level results in the most profound differences between national laws on the establishment of parenthood. After all, a difference at the first level means that legal systems differ as to who should be the legal parent of the child in abstracto. It will appear that legal systems differ regarding the starting-point of their laws on legal affiliation. Since these differences have been maintained or even reinforced in the course of recent national modifications, it seems that at a national level we are diverging, especially when it comes to the consequences of assisted reproduction.

\subsection{Grounds for legal affiliation}

The ground or grounds for legal affiliation in a national legal system are the central idea or ideas around which the rules on legal affiliation are built. It concerns central ideas on who should be the parent of a child for legal purposes. An obvious question is how one finds the ground for legal affiliation in a certain national legal system. Unfortunately no legislator works as systematically as the hypothetical legislator described above. The answer is therefore that it depends on the legal system involved. Sometimes the grounds are stated expressly in the law of the legal system involved, as is done in Sweden for cases involving assisted reproduction. Sometimes the grounds 
have to be derived from the provisions on judicial establishment of legal parenthood and annulment of legal parenthood, as is the case in France, Germany and the Netherlands. In that case, it is submitted that the fact that has to be proved (e.g. genetic affiliation or consent to fertility treatment) in order to establish or annul legal parenthood is the central idea for the purpose of the proposed model. This point needs some further explanation.

How do we know that the central idea of a legal system is found by peeling away the provisions on judicial establishment and annulment of legal parenthood? The answer is that we don't. Concepts like 'starting point' or 'ground' are not something which is used by the respective legislators. The fact that most legislators did not work according to the model which has been described above already indicates that they were probably not aware of something like a ground for legal affiliation and additional interests on the basis of which one can deviate from that ground. They were simply craftsmen taking up their task employing the tools which had been handed down by previous legislators. The central idea or the ground for legal affiliation are concepts which have been invented in order to be able to create a model which fits all the national laws into the present comparison. Consequently, the model only presents a certain perspective on what is out there in the different legal systems on legal affiliation. Although the model does not represent the absolute truth, its formulation is not at all gratuitous. On the one hand, it should fit all the legal systems in order to facilitate the comparison, but, on the other hand, it should give a fair impression of the actual content of the legal systems considered.

\subsubsection{Grounds for legal maternity}

A study of the laws on legal affiliation in England \& Wales, France, Germany, the Netherlands and Sweden reveals that there are two grounds for the establishment of legal maternity: childbirth and social affiliation (apparent status or possession d'état). Legal systems differ as to which grounds they use and to which situations a certain ground applies.

\subsubsection{Childbirth}

Childbirth is the ground for legal maternity in the case of natural reproduction and assisted reproduction in all legal systems involved. Under Dutch and German law this ground follows directly from the Civil Code itself, which states that the woman who 
gives birth to the child shall be the child's legal mother. ${ }^{5}$ The same holds true for English $^{6}$ and Swedish law. ${ }^{7}$

The French Civil Code does not expressly provide who should be the legal mother of the child. It only provides how legal maternity can be established and annulled: legal maternity under French law is defined formally, not substantially. However, it is apparent from the provisions of the Civil Code that the legislative aim is to establish the legal maternity of the woman who gave birth to the child. First, Article 332 French Civil Code states that legal maternity can be annulled if it is proved that the legal mother did not give birth to the child. Second, Article 55 French Civil Code states that the birth has to be declared within three days after the birth of the child, which indicates that the woman who gives birth to the child should be mentioned in the birth register as the child's mother. However, it should be mentioned immediately that the birthmother will not in all cases indeed be the legal mother of the child, as will explained below, at 1.3 .

It could be argued that childbirth in fact is not really the essence of the law on legal affiliation. One could argue that in case of natural reproduction legal maternity is based on genetic affiliation and that in case of differentiated maternity, i.e. the case where the woman who carries the child is not the child's genetic mother, the legislator based legal maternity on the intention of the birthmother to get the child. However, it turns out that in the legal systems under consideration legal maternity is only based on intention if the birthmother is not the genetic mother of the child. The intention of the genetic mother in such a case is not honoured in any of the legal systems involved, at least not immediately. ${ }^{8}$ From the parliamentary history of legislation on parenthood in

\footnotetext{
${ }^{5}$ Article 1:198 Dutch Civil Code; Article 1591 German Civil Code.

${ }^{6}$ In case of natural reproduction, or, more specifically, in cases to which the Human Fertilisation and Embryology Act 1990 does not apply, childbirth as a ground for legal maternity follows from the Ampthill Peerage Case [1977] A.C. 547, at 577. Also S.M. Cretney e.a., Principles of Family Law, London: Sweet \& Maxwell (2003), p. 523. In case of assisted reproduction Article 27 Human Fertilisation and Embryology Act 1990 also provides that the woman who gives birth to the child shall be the child's legal mother.

${ }^{7}$ Swedish law has no specific provisions on legal maternity in the situation of natural reproduction. It was considered self-evident that the woman who gives birth to the child was the child's mother. The fact that the woman who gives birth to the child is the child's legal mother has to be derived from the Registration Act (Folkbokföringslag (1991:481)), which links the registration of parents directly to the birth of the child (Socialstyrelsen, Att fastställa faderskap, Stockholm: Elanders Gotab (2005), p. 105). Nowadays Article 1:7 of the Föräldrabalk (1949:381) (Children and Parents Code) provides that if a woman gives birth to a child who has been created with the ovum of another woman, the woman who gives birth to the child shall be considered to be the child's mother .

${ }^{8}$ Under English law the genetic mother can acquire parental rights under certain circumstances, but even under English law the guiding rule is that the birth mother is the child's mother (cf. Human Fertilisation and Embryology Act 1990, section 27 and 30ff).
} 
the last few years in, for example, the Netherlands and Germany, it appears that the rule that the birth mother is always the legal mother is meant to discourage or ban surrogacy constructions. ${ }^{9}$ It seems that the act of giving birth is strongly connected with the idea of maternity and therefore intention is probably not an essential concept in case of legal maternity and assisted reproduction.

\subsubsection{Apparent status or possession d'état}

The second ground for legal affiliation is apparent status. ${ }^{10}$ The concept of apparent status or possession d'état is typical for French law on legal affiliation, but it also exists in other legal systems, such as the Dutch legal system, which have been influenced by French law. Possession d'état literally means possession of status. One possesses a certain status by exercising the rights and performing the duties associated with a certain personal status. Here possession d'état has been translated as apparent status, since the personal status one possesses is determined by apparent facts. If a child has a certain apparent status, it means that from apparent facts it appears that a certain man or woman is the (legal) father or mother of the child. Such facts are that the child is being raised and supported by the man and the woman, that the child bears their name and that society in general and the administration considers the man and the woman to be the child's legal parents. ${ }^{11}$ This is not the place to explain the ins and outs of the concept of apparent status. ${ }^{12}$ What is important is that apparent status is not dependent on genetic affiliation: one can have the apparent status of being a certain person's child, without being the genetic child of that person. ${ }^{13}$

Apparent status is only a qualification of a certain fact-pattern and as such the concept is universal. However, the function it has differs among the countries that use the concept. For example, under Dutch law the concept is only used to prevent actions for annulment of legal affiliation. ${ }^{14}$ The rationale behind that Dutch rule is that if apparent status indicates that a certain person is the child's legal mother or father, apparently a certain social reality has crystallised and it is deemed undesirable to

\footnotetext{
${ }^{9}$ Germany: BR Drucks. 180/96, p. 92 and BT Drucks. 13/4899, p. 82. The Netherlands: Second Chamber, 1995/96, 24 649, nr. 3 (explanatory report), p. 7

${ }^{10}$ Also A. Bénabent, Droit civil la famille, Paris: Litec (2001), nr. 580.

${ }^{11}$ Cf. Article 311-1 French Civil Code.

12 For an exhaustive explanation of apparent status under French law: V. Morgand-Cantegrit, La possession d'état d'enfant, Thèse Université de Lille II Droit et Santé (1993). See also D. Huet-Weiler, 'L'établissment de la filiation par la possession d'état', Recueil Dalloz Sirey (1982), 185-192; M. Rèmond-Gouilloud, 'La possession d'état d'enfant', Revue Trimestrelle de Droit Civil (1975), 459-481.

${ }^{13}$ Cf. P. Malaurie \& H. Fulchiron, Droit civil: La famille, Paris: Défrenois (2006), p. 387.

${ }^{14}$ Article 1:209 Dutch Civil Code.
} 
disrupt that social reality. ${ }^{15}$ Under French law apparent status even has the function of a ground for establishment of legal affiliation for the same reason; according to the French legislator social reality should be clearly reflected in the legal situation. ${ }^{16}$ Therefore, if under French law the apparent status of a child is that he or she is the legal child of a certain woman, that woman is by dint of that very fact the child's legal mother, provided that the apparent status has been recorded in an affidavit. ${ }^{17}$ On the basis of this assertion it would still be possible to argue that apparent status is only a means of establishing legal maternity. However, legal maternity based on the existence of apparent status cannot be annulled by proving that the legal mother did not give birth to the child: the applicant has to prove that the child's apparent status at the moment legal maternity was established did not indicate that the woman in question was the child's legal mother. ${ }^{18}$

\subsubsection{The relationship between genetic affiliation and apparent status under French law}

The fact of coexistence of two grounds for legal maternity under French law, raises the question as to when apparent status is a ground for legal affiliation and when childbirth is such a ground. There is no distinctive fact-pattern for genetic affiliation and apparent status; both can apply in the same case, but not together. This follows from the system of French law on affiliation. Article 310-1 French Civil Code provides that legal affiliation is established by registration, acknowledgement, apparent status or judicial establishment. Apparent status can only serve as a means to establish legal affiliation if the existence of apparent status has been recorded either in an affidavit (Article 310-1 in conjunction with Article 317 French Civil Code) or in a judgment (Article 330 French Civil Code). Legal affiliation based on apparent status can be annulled on the basis of Article 335 French Civil Code, if it has been recorded

\footnotetext{
15 On apparent status under Dutch law see K. Saarloos, 'Bezit van staat of het wormvormige aanhangsel van het Nederlandse afstammingsrecht?' Weekblad voor privaatrecht, notariaat en registratie 2006, p. 123-129.

${ }^{16}$ On the role of apparent status and the importance of 'social affiliation' in French law see F. Dekeuwer-Defossez (e.a.), Rénover le droit de la famille: propositions pour un droit adapté aux réalités et aux aspirations de notre temps, Paris : La documentation française (1999) and I. Théry, Couple, filiation et parenté aujourd'hui: le droit face aux mutations de la famille et de la vie privée, Paris : La documentation française (1998).

${ }^{17}$ Article 310-1 French Civil Code.

${ }^{18}$ Article 335 French Civil Code. See also F. Granet-Lambrechts \& J. Hauser, 'Le nouveau droit de la filiation', Recueil Dalloz 2006, p 17-28, at p. 23. However, Massip states that legal affiliation on the basis of apparent status can also be annulled by proving the absence of genetic affiliation (J. Massip, Le nouveau droit de la filiation, Paris: Défrenois (2006), p. 57). Cf P. Malaurie \& H. Fulchiron, Droit civil: La famille, Paris: Défrenois (2006), p. 571.
} 
in an affidavit. According to Article 320 French Civil Code, the establishment of legal affiliation is not possible if legal affiliation with another person already exists. In that case, the first relationship has to be annulled before a new relationship can be established. In other words, it is not possible to establish legal maternity by means of apparent status if the child has been acknowledged by another woman and if that acknowledgment has not been annulled. This does not mean that apparent status as such cannot exist in such a case. On the contrary, it is possible that woman X first acknowledged the child, but that the child later on develops apparent status with woman Y. In that case, the apparent status does not establish the legal maternity of woman $\mathrm{Y}$. The only consequence is that the acknowledgment of the child by woman $\mathrm{X}$ is easier to annul: if the acknowledgment is not in conformity with the apparent status everyone with an interest can apply for annulment of the acknowledgment within ten years of the date of the acknowledgment (Article 334 French Civil Code). If the acknowledgment is in conformity with the child's apparent status, the acknowledgment can only be annulled upon application by the child, the legal parents or the person who claims to be the child's biological parent. These persons have to apply before the acknowledgment and the apparent status have been in conformity for five years (Article 333 French Civil Code).

\subsubsection{Grounds for legal paternity}

The grounds for legal paternity are far more complicated to describe than the grounds for legal maternity. First, it is submitted that, in the legal systems which have been examined in this study, there are three grounds for legal affiliation: genetic affiliation, intention and apparent status. However, not only do legal systems differ according to whether or not these grounds are used at all in the laws on legal affiliation, but they also differ as to the situations in which the grounds apply. For example, under all legal systems intention is a ground for legal affiliation if the child has been born as a result of fertility treatment. However, not all legal systems define the scope of application of the rules on legal affiliation in case of fertility treatment in the same way. Moreover, in a model which aims to fit all the legal systems under consideration, it is formally not correct to speak of legal paternity. After all, as explained above, under Swedish law the second parent (apart from the mother) can, under certain circumstances, also be female if she is the mother's consenting partner and if the 
fertility treatment took place within the framework of Swedish law. ${ }^{19}$ This paragraph will discuss genetic affiliation and intention as a ground for legal parenthood. Apparent status as a ground for legal paternity will not be discussed here. It is only a ground for legal paternity under French law and the discussion on apparent status as a ground for legal maternity applies equally to legal paternity.

\subsubsection{Genetic affiliation}

In the case of natural reproduction, genetic affiliation is the ground for legal paternity in all the five legal systems under consideration. Under English law this proposition follows from the unwritten rules of common law. ${ }^{20}$ In the other legal systems the proposition has to be derived from the grounds for judicial establishment and annulment of legal paternity: in case of natural reproduction, all legal systems provide that one has to prove either the existence or the absence (depending on the action) of genetic affiliation. $^{21}$

\subsubsection{Intention}

Intention as a ground for legal affiliation is less straightforward than genetic affiliation. The deployment of intention as a ground implies that the intention as such to become the parent of a child is sufficient to actually become the legal parent, without it being possible to annul the legal parenthood on the basis of another ground. Therefore voluntary acknowledgment of paternity in case of natural reproduction in this model is not based on intention, although in most legal systems acknowledgment of paternity only requires that the acknowledger has full legal capacity (as for all legal acts) in order for the acknowledgement to be effective; the validity of the acknowledgment does not depend on the genetic reality. However, it is important that

\footnotetext{
${ }^{19}$ Article 1:9 Children and Parents Code (1949:381).The possibility for the lesbian partner of the mother to become the child's legal mother has been inserted by Act SFS 2005:434 and entered into force on the $1^{\text {st }}$ of July 2005. On the Swedish law see i.a. M. Jänterä-Jareborg, 'Sweden: Lesbian couples are entitled to assisted fertilisation and to equal rights of parentage', Zeitschrift für das gesamte Familienrecht (2006), p. 1329-1330.

${ }^{20}$ S.M. Cretney e.a., Principles of Family Law, London: Sweet \& Maxwell (2003), p. 524; Halsbury's Laws of England, Children and Young Persons, London: Butterworths (2001), par. 93, p. 54.

${ }^{21}$ Articles 327 and 332 French Civil Code, Article 1599 (1) German Civil Code (German law does not specify the ground for judicial establishment of paternity, but it is generally accepted that in case of judicial establishment of paternity under German law, it has to be proved that the respondent is the child's genetic father (Staudinger's Kommentar zum BGB, Part IV/Rauscher, Berlin: Sellier - de Gruyter (2004), p. 474; Münchener Kommentar zum BGB Volume 8/Seidel (2002), p. 224), Articles 1:200 (1), 1:205 (1) and Art. 1:207 Dutch Civil Code and Articles 1:2, 1:4 (3) and 1:5 Swedish Children and Parents Code (1949:381).
} 
it is at least presumed that the acknowledger is the child's genetic father. ${ }^{22}$ This presumption is evidenced by the fact that, apart from cases of assisted reproduction, the acknowledgment can be annulled if it is not in conformity with genetic reality. ${ }^{23}$ The fact that the action for annulment of acknowledgment is severely restricted under some legal systems does not weaken the point now being made. After all, it is submitted that the restrictions on an action for annulment of acknowledgment are imposed by the fact that in that legal system genetic affiliation is not a goal in itself but merely a starting-point. The establishment of legal affiliation by means of the acknowledgment of parenthood will be explained in more detail below.

Intention within the meaning of this model is the ground for the establishment of legal paternity in case of assisted reproduction in all legal systems under consideration except under Dutch and German law.

Under English ${ }^{24}$ and Swedish law ${ }^{25}$ the law provides explicitly that intention is a ground for legal affiliation. The fact that intention is a ground for legal paternity under French law has to be inferred from the law on legal affiliation. In particular, it can be inferred from Article 311-20 French Civil Code which explicitly provides that legal paternity cannot be annulled if the legal father consented to the assisted reproduction even if he is not the child's genetic father. Moreover, that article also provides that the man who consented to the assisted reproduction is obliged to acknowledge paternity.

Under Dutch and German law intention as such is not a ground for legal paternity, since the child is able to annul legal paternity if the man is not the child's genetic father, even if the man consented to the fertility treatment. Under these rules only the legal mother and father are barred from applying for annulment of legal

\footnotetext{
${ }^{22}$ For the Netherlands see: Kamerstukken II 2004/05, 28457 and 26 672, nr. 23, p. 3; : A.J.M. Nuytinck, 'Het gezag over minderjarige kinderen en de andere levensgezel' Weekblad voor Privaatrecht, Notariaat en Registratie 2006, p. 885-888, p. 887; Asser/de Boer (2002), p. 632; S. Wortmann, 'Sekseneutraal afstammingsrecht?' Tijdschrift voor familie- en jeugdrecht 2001, p. 231236, p. 235; A. Willems, 'Adoptie door homo-ouders en de positie van de spermadonor' Tijdschrift voor familie- en jeugdrecht 2000, p. 226-229, p. 228; P. Vlaardingerbroek, 'Adoptie door paren van gelijk geslacht' Tijdschrift voor familie- en jeugdrecht 2000, p. 198-202; Rapport Commissie inzake openstelling van het burgerlijk huwelijk voor personen van hetzelfde geslacht, Den Haag, October 1997, p. 7.

${ }^{23}$ Germany: Article 1599 German Civil Code; France: Article 332 French Civil Code; the Netherlands: Article 1:205 Dutch Civil Code; Sweden: Article 1:4 Children and Parents Code (1949:381). In English law acknowledgment of paternity does not exist as such since legal parenthood always exists ex lege (see below).

${ }^{24}$ Section 27 Human Fertilisation and Embryology Act 1990.

${ }^{25}$ Article 1:6 and 1:8 Children and Parents Code (1949:381).
} 
paternity if the legal father consented to the assisted reproduction. ${ }^{26}$ The reason given for this rule under German law is that the child has a constitutionally protected right to know its genetic origins. ${ }^{27}$ Under Dutch law it is possible to obtain information regarding one's genetic ancestors without it being necessary to establish legal affiliation with the genetic parents. ${ }^{28}$

There are further indications that intention is not a ground for legal affiliation under Dutch and German law. Under Dutch law, the fact that the acknowledger consented to the assisted reproduction is not, as such, a bar to an application by the child's legal parents for annulment of the acknowledgment. The only ground for annulment of acknowledgment under Dutch law is that the acknowledger is not the child's biological father. ${ }^{29}$ This submission should, however, be refined. First, the child's legal parents are only allowed to apply for annulment of acknowledgment if they can show that, at the moment of the acknowledgment, they lacked capacity either to acknowledge or to consent. ${ }^{30}$ Moreover, should an applicant actually pass this hurdle, the annulment of acknowledgment against the mother's or child's will would be without effect, since the mother and child have the possibility to reverse the annulment by exercising their right to apply for judicial establishment of his legal paternity on the basis of Article 1:207 Dutch Civil Code. So, although the parent's right to apply for annulment of acknowledgment exists if the acknowledger, although not the genetic father of the child, consented to the assisted reproduction, this right is certainly not unconditional.

The fact that intention is not a ground for legal affiliation under German law is furthermore demonstrated by the fact that judicial establishment of paternity on the basis that the man consented to the assisted reproduction is not possible. Only the paternity of the genetic father can be judicially established. ${ }^{31}$

\footnotetext{
${ }^{26}$ Article 1600 (4) German Civil Code; Articles 1:200 (3) and 1: 205 (1) Dutch Civil Code.

${ }^{27}$ J. Gernhuber \& D. Coester-Waltjen, Familienrecht, München: Verlag C.H. Beck (2006), p. 627.

${ }^{28}$ On the right to know one's genetic affiliation under Dutch law: J. de Boer, Asser's Personen en Familierecht, Deventer: Kluwer (2002), p. 496; C. J. Forder, Legal Establishment of the Parent-Child Relationship: Constitutional Principles in Dutch, English and German Law, having Regard to the European Convention for the Protection of Human Rights and Fundamental Freedoms and Other Applicable Instruments, Maastricht, 1995, p. 126-139. Independent of the legal affiliation status of the child, the child can obtain information about his or her genetic affiliation under the Donor Information Act 2002 (Wet donorgegevens kunstmatige bevruchting, Stb. 2002, 240).

${ }^{29}$ Article 1:205 (1) Dutch Civil Code.

${ }^{30}$ Article 1:205 (1) under b and c Dutch Civil Code.

${ }^{31}$ See note 21 .
} 
So far we have seen that, under all legal systems reviewed, intention is not a ground for the establishment of legal affiliation. However, even among the legal systems according to which intention is a ground for legal affiliation, the application of the ground is not the same. Legal systems which use intention as a ground for legal affiliation use it differently. Firstly, the field of application of intention as a ground for legal affiliation differs among between countries involved. Secondly, the elements which are required to constitute a valid expression of the intention differ. These differences will be explored in more detail.

\section{a. Definition of the field of application of intention as a ground for legal affiliation}

In order to determine the field of application of intention as a ground for legal affiliation the field of application of the rules on the consequences of assisted reproduction for the legal affiliation status of the child must be defined. The reason is that intention as a ground for legal affiliation only exists in cases where the child has been born as a result of assisted reproduction. However, not all the provisions which have been enacted to regulate the consequences of assisted reproduction can be taken to signify that intention has been accepted as a ground for legal affiliation. We have already shown that under Dutch and German law this is not the case. Accordingly, a definition of the field of application of the national provisions regarding the consequences of assisted reproduction in all the countries under consideration is, strictly spoken, not necessary. However, the scope of application of the Dutch and German provisions on assisted reproduction will be discussed nonetheless, for the sake of completeness.

Under Dutch law, the rule that the consenting husband cannot annul marital paternity (Art.1:200 (3) Dutch Civil Code) and the rule that the paternity of the consenting partner can be judicially established (Article 1:207 Dutch Civil Code) applies in all cases where the mother's partner consented to the conception of the child, even if the conception took place naturally. It should be stressed that the provisions are not confined to consent to assisted reproduction. This follows from Article 1:200 Dutch Civil Code which provides that the legal paternity of the mother's husband cannot be annulled if he consented to the act which could have resulted in the procreation of the child and Article 1:207 Dutch Civil Code, which provides that legal 
paternity can be established on the same basis if the man was the partner of the child's mother at the moment at which he consented. ${ }^{32}$

Under French law, the field of application of intention as ground for legal affiliation is narrower than under Dutch law. It applies to all cases where the child has been born as a result of medically-assisted fertility treatment with donor semen (procréation médicalement assistée avec tiers donneur). ${ }^{33}$ If the child is not born as a result of fertility treatment with donor semen, genetic affiliation is the ground for legal paternity under French law. Hence, if the child is born after private insemination, i.e. without medical assistance, intention will not be a ground for legal affiliation under French law. This does not mean, however, that the private donor cannot, in a concrete case, become the child's legal parent, but it means that the establishment of him as the child's father will be susceptible to annulment.

Although German law does not recognise intention as a ground for legal affiliation, a specific consequence is nevertheless attached to the fact that a child has been born as a result of assisted reproduction. Article 1600 (4) German Civil Code provides that the child's legal father and mother are not allowed to apply for annulment of legal paternity if the legal father consented to the fertility treatment. However, since it is not possible to judicially establish that the consenting partner is the child's father, the field of application is limited to the situation in which the child is born to a married couple or to the situation in which the consenting partner became the legal parent through voluntary acknowledgement of paternity.

English law, moreover, has its own peculiar definition of the scope of application for intention as a ground for legal affiliation. The provisions on the consequences of assisted reproduction on the legal affiliation of the child, contained in the Human Fertilisation and Embryology Act 1990, only apply if the child is born as a result of the placement of an embryo or of sperm and ova in the woman's uterus or as a result of artificial insemination. ${ }^{34}$ Moreover, if the treatment is provided to an unmarried couple the rule only applies if the treatment took place in a licenced

\footnotetext{
32 'The act which could have resulted in the conception of the child' should be correctly understood. In a decision of the 7th of February 2003 (NJ 2003/358), the Dutch Supreme Court held that the husband who consented to and encouraged his wife to commit acts of prostitution could not annul the relationship of legal paternity between himself and the child born as a result of the prostitution. According to the Supreme Court, the husband consented to an act which could have resulted in the conception of the child.

${ }^{33}$ Article 311-20 French Code Civil.

${ }^{34}$ Articles 27 and 28 Human Fertilisation and Embryology Act 1990.
} 
hospital within the meaning of the Human Fertilisation and Embryology Act $1990 .{ }^{35}$ Hence, if the treatment took place abroad and was provided to an unmarried couple, intention cannot provide a ground for legal affiliation. In fact, it will be impossible to establish that the male consenting partner was the father of the child born in consequence of the treatment. Whether genetic affiliation is a ground for legal affiliation in such a case depends on who provided the sperm which was used for the treatment. If the sperm comes from a sperm donor within the meaning of 28 (6) Human Fertilisation and Embryology Act 1990 or if the sperm of a deceased person has been used, ${ }^{36}$ genetic affiliation is not a ground for legal affiliation and the genetic father cannot be established to be the child's father. As a consequence, the child remains fatherless. ${ }^{37}$

Finally under Swedish law, the demarcation of the scope of application of intention as a ground for legal affiliation depends on whether the consenting partner is male or female. If the consenting partner is male, intention is a ground for legal affiliation if the child is born in consequence of insemination (insemination) or fertilisation of the mother's ovum outside her body (befruktning av moderns ägg utförts utanför hennes kropp). ${ }^{38}$ However, if the consenting partner is female the treatment must take place within the Swedish legal framework for this kind of treatment if intention is te be treated as a ground for legal affiliation according to Swedish law. As a consequence of the structure of Swedish affiliation law, the female consenting partner can never become the legal parent if the treatment took place outwith the Swedish legal framework. ${ }^{39}$

\section{b. Differences between national provisions on the consequences of assisted reproduction}

The contents of the provisions on the consequences of assisted reproduction differ considerably. The provisions in the legal systems studied on the consequences of assisted reproduction for legal affiliation are typically built on four variables. These

\footnotetext{
${ }_{35}^{35}$ Article 28 (3) under a Human Fertilisation and Embryology Act 1990.

${ }^{36}$ Post-mortem registration of paternity is only symbolic and does not confer any rights on the child. On the question of post-mortem registration of paternity see Sections 28 (5A) to (5D) and (5I) Human Fertilisation and Embryology Act 1990. On the background of the provisions and the consequence of the registration for the status of the child see the explanatory notes to the Human Fertilisation and Embryology (Deceased Fathers) Act 2003, par. 4. See also N. Lowe \& G. Douglas, Bromley's Family Law, Oxford University Press (2007), p. 311.

${ }^{37}$ See also S.M. Cretney e.a., Principles of Family Law, London: Sweet \& Maxwell (2003), p. 526; Lee \& Morgan, Human Fertilisation and Embryology. Regulating the reproductive revolution, London: Blackstone 2001.

${ }^{38}$ Articles 1:6 and 1:8 Children and Parents Code (1949:381).

${ }^{39}$ Article 1:9 Children and Parents Code (1949:381). See also prop. 2004/05:137, p. 44.
} 
variables are: the partner's consent to the fertility treatment; the relationship between the mother and the consenting partner; the object of the consent; and the causal relationship between the approved treatment and the conception of the child and the spatial reach of the provisions on the consequences of assisted reproduction.

The first variable is the consent. A person who is not the child's genetic parent will only be considered to be the parent if he or she consented to the treatment. However, systems differ as to the formal requirements of the consent and as to events which render the consent ineffective. Most countries do not require any formalities for the consent to be effective. This is the case in England \& Wales, ${ }^{40}$ Germany ${ }^{41}$ and the Netherlands. In Sweden this is only the case in so far as it concerns the mother's male partner. ${ }^{42}$ If the consenting partner is female, her consent has to be in writing in order for her to be considered the child's parent. ${ }^{43}$ In France, the requirements for a valid consent are more demanding. According to Article 311-20 Code Civil the consenting partner will only be the legal father if his consent has been given before a judge or a civil law notary who has to inform the couple of the legal consequences of the consent.

Another important aspect of consent concerns the circumstances under which the consent is deemed to be ineffective. Some legal systems have legal provisions which render the consent automatically ineffective. Other legal systems have formal requirements as to how the consent should be withdrawn and before which time. French law provides an example. The consent of one of the partners becomes ineffective if the consenting person dies or if the couple applies for divorce or any other comparable action. Under French law, a person can also withdraw his or her consent, but the withdrawal has to be in writing in order to be valid and the doctor in attendance has to be notified of the withdrawal. Moreover, it follows from Article 311-20 French Civil Code that consent can only be invalidated before the treatment takes place. However, Dutch and German law do not contain provisions on these issues.

\footnotetext{
${ }^{40}$ S.M. Cretney e.a., Principles of Family Law, London: Sweet \& Maxwell (2003), p.525.

${ }^{41}$ J. Gernhuber \& D. Coester-Waltjen, Familienrecht, München: Verlag C.H. Beck (2006), p. 628; Staudinger's Kommentar zum BGB, Part IV/Rauscher, Berlin: Sellier - de Gruyter (2004), p. 390.

${ }^{42}$ A valid consent only requires that the man is able to determine his will (e.g. that he is not mentally ill), G. Walin, Föräldrabalken och internationell föräldrarätt, Stockholm: Norstedt (1996), p. 81.

${ }^{43}$ Article 1:9 Children and Parents Code (1949:381) provides that the female partner of the child's mother is only the child's legal parent if the fertility treatment took place within the framework of the Lag (2006:351) om genetisk integritet m.m. Article 6:1 and 7:3 Lag (2006:351) om genetisk integritet $m . m$. provides that the consent to the fertility treatment has to be in writing.
} 
The second variable is the relationship between the consenting person and the mother. The question is whether there has to be a certain relationship (marriage, partnership etc.) between the mother and the consenting person before the consent of that person can serve as a basis for legal affiliation. All legal systems require that there is a certain relationship between the mother and the consenting person, although English law is ambiguous in this matter. English law provides that, if the treatment takes place out of wedlock, the consenting partner is only the child's legal father if he and the mother received treatment together. 'Receiving treatment together' does not mean that the persons should be married or living together. What it does mean is not entirely clear. ${ }^{44}$ In France the couple has to be married or the man and the woman have to live together. ${ }^{45}$ The same holds true under the legal system of the Netherlands ${ }^{46}$ and Sweden. ${ }^{47}$

The third variable is the object of the consent and the causal relationship between the treatment and the conception of the child. Regarding the object, Dutch law is the only exception to the rule that the man should have consented to fertility treatment. Under Dutch law, consent is a basis for legal affiliation if the husband or the partner consented to the act which could have resulted in the begetting of the child. ${ }^{48}$ Under the laws of England \& Wales, France, Germany and Sweden the partner has to consent to the fertility treatment.

As to the causal relationship between the fertility treatment and the birth of the child in question there is more diversity. Dutch ${ }^{49}$ and Swedish law ${ }^{50}$ provide that it must be likely that the child was born as a result of the fertility treatment. Neither legal system specifies whether it is possible to prove that the child was not born in consequence of the treatment. English and German law is stricter; the consenting

\footnotetext{
${ }^{44}$ There is some case law on the meaning of 'receiving treatment together'. See N. Lowe \& G. Douglas, Bromley's Family law, Oxford University Press (2007), p. 313. See also S.M. Cretney e.a., Principles of Family Law, London: Sweet \& Maxwell (2003), p. 525.

${ }^{45}$ Article 311-20 French Civil Code.

${ }^{46}$ Articles 1:200 and 1:207 Dutch Civil Code.

${ }^{47}$ Articles 1:6, 1:7 and 1:8 Children and Parents Code (1949:381).

${ }^{48}$ See also note 32 .

49 Articles 1:200 and 1:207 Dutch Civil Code provide that the man must have consented to the act which could have resulted in the conception of the child.

${ }^{50}$ Articles 1:6, 1:7 and 1:8 Children and Parents Code (1949:381) provide that it must have been sannolikt that the mother's child has been created as a result of the fertility treatment to which the man (or woman) consented. Sannolikt more or less means 'likely'. However, the term should be understood in its context. Sannoligt is an adjective which indicates the second highest burden of proof. The highest burden of proof is that the one has to prove that something is utrett (proven). On the different burdens of proof in Swedish law on legal affiliation see A. Saldeen, Faststellende av faderskap, Stockholm: Norstedts (1980), p. 55.
} 
partner is only the child's father if the child was born as a result of fertility treatment to which the father consented. Hence it is possible to prove that the child was not conceived as a result of the agreed treatment. ${ }^{51}$ French law provides explicitly that it is possible to prove that the child is not the result of the fertility treatment to which the husband consented.

The fourth variable is probably the most exciting one. It concerns the spatial reach of the provisions regarding the consequences for legal affiliation in the context of assisted reproduction. In most legal systems the rules on the consequences for legal affiliation apply notwithstanding the place where the treatment took place. This is only different for parts of the English and Swedish legal system. It has been pointed out above that under Swedish law the consent of the mother's female partner has to be in writing in order for the provisions on the consequences of assisted reproduction to apply. In fact, Article 1:9 Children and Parents Code (1949:381) provides that the whole treatment has to take place within the framework of the Swedish law on assisted reproduction (Lag om genetisk integritet m.m. (2006:351)) for the female partner to be able to become the child's parent. Swedish law even appoints the kind of hospital where the treatment has to take place. ${ }^{52}$ It follows that if two Swedish women receive treatment abroad and if the child is born in Sweden, the mother's female partner will not be considered to be the child's mother. A similar provision is found in the English Human Fertilisation and Embryology Act 1990 in relation to the consequences of assisted reproduction out of wedlock. Section 28 (3) of the Act provides that the consenting partner who is not the child's genetic father shall only be the legal father if the fertility treatment was provided for him and the mother together 'by a person to whom the licence applies'. Only institutions established in the United Kingdom can obtain a licence. If the treatment took place abroad, the consenting partner will not be considered to be the child's legal father if he is not the genetic father. $^{53}$

\footnotetext{
${ }^{51}$ For English law: Leeds Teaching Hospital NHS Trust v. A [2003] EWHC 259 (QB), [2003] 1 FLR 1091. The court held that the husband was not the father, since he could not be taken to have consented to the treatment of his wife, who was - accidentally - impregnated by someone else's sperm. Cited in N. Lowe \& G. Douglas, Bromley's Family law, Oxford University Press (2007), p. 313. For German law see L. Müller in R. Hoppenz (ed.), Familiensachen, Heidelberg: C.F. Müller Verlag (2005), p. 537. Staudinger's Kommentar zum BGB, Part IV/Rauscher, Berlin: Sellier - de Gruyter (2004), p. 392.

${ }^{52}$ Article 6:2 and 7:4 Lag (2006:351) om genetisk integritet m.m.

${ }^{53}$ N. Lowe \& G. Douglas, Bromley's Family law, Oxford University Press (2007), p. 314; Lee \& Morgan, Human Fertilisation and Embryology. Regulating the reproductive revolution, Blackstone 2001, p. 221.
} 


\subsubsection{Grounds for legal parenthood-overview}

So far we have discussed the grounds for legal affiliation under the laws of England \& Wales, France, Germany, the Netherlands and Sweden. For the sake of clarity the following table gives an overview of this examination.

\begin{tabular}{|l|l|l|l|l|}
\hline \multirow{2}{*}{} & \multicolumn{2}{|l|}{ Legal maternity } & \multicolumn{2}{l|}{ Legal paternity (or second mother) } \\
\cline { 2 - 5 } & $\begin{array}{l}\text { Natural } \\
\text { reproduction }\end{array}$ & $\begin{array}{l}\text { Assisted } \\
\text { reproduction }\end{array}$ & $\begin{array}{l}\text { Natural } \\
\text { reproduction }\end{array}$ & $\begin{array}{l}\text { Assisted } \\
\text { reproduction }\end{array}$ \\
\hline $\begin{array}{l}\text { England } \\
\text { Wales }\end{array}$ & Childbirth & Childbirth & Genetic affiliation & Intention \\
\hline France & $\begin{array}{l}\text { Childbirth } \\
\text { Apparent status }\end{array}$ & $\begin{array}{l}\text { Childbirth } \\
\text { Apparent status }\end{array}$ & Genetic affiliation & Intention \\
\hline Germany & Childbirth & Childbirth & Genetic affiliation & Genetic affiliation \\
\hline The Netherlands & Childbirth & Childbirth & Genetic affiliation & Genetic affiliation \\
\hline Sweden & Childbirth & Childbirth & Genetic affiliation & Intention \\
\hline
\end{tabular}

\subsection{Establishment and annulment of legal parenthood}

The previous paragraph has shown what is at the heart of a national system of legal affiliation. It has not shown how a person becomes the child's legal parent. The establishment of legal affiliation is therefore the subject of this third paragraph. The establishment of legal affiliation is also the second layer in the model which we deploy to describe and compare the national laws on legal affiliation. This paragraph aims to describe two things. First, there are four ways of establishing legal parenthood: automatically or ex lege; as a result of apparent status; by acknowledgement or by judicial establishment of paternity. Legal systems differ as to which methods they use and how they use them and it is the aim of this paragraph to analyse these differences. One important difference between ex lege establishment of legal affiliation and the other methods has to be mentioned in advance. In case of $e x$ lege establishment of legal affiliation the legal affiliation will (almost) always be in conformity with the ground for legal affiliation (the only exception is the ex lege establishment of the legal paternity of the mother's husband). For this reason, legal systems provide for systems for annulment of legal affiliation. However, the possibility to apply for annulment of legal parenthood is often not unconditional. Hence, there are two moments in the law on establishment of legal affiliation at which the legislator has to make policy considerations. The first is at the moment at which the legislator has to choose between ex lege establishment of legal affiliation, with the certainty that legal parenthood will always be in conformity with the ground for legal affiliation, and any other method of establishment of legal affiliation which does not

\footnotetext{
${ }^{54}$ If the provisions on the consequences of assisted reproduction apply.
} 
offer this guarantee. The second important moment for policy considerations is when the legislator has to come up with a system for annulment of legal parenthood. The legislator has to determine to what extent it is acceptable to annul an existing legal relationship which has such a profound impact on the private life of the individuals involved.

The second aim of this paragraph is therefore to give insight into the reasons for deviating from the starting-point for establishing legal affiliation in a national legal system. It will turn out that there are not always very clear policy considerations for a certain regulation. Tradition and the system of law have played an important role in the establishment and annulment of legal parenthood.

Hereafter, the four methods of establishing legal parenthood will be described. It will be explained how they work and how they are applied in the various legal systems. After that, a comparative overview of the legal regulations on annulment of legal parenthood will be presented.

\subsubsection{Establishment of parenthood - four methods}

\subsubsection{Ex lege existence of parenthood}

Ex lege existence of parenthood means that legal parenthood exists automatically, without any legal action being required to be taken once the requirements are fulfilled as laid down in the law. Characteristic for the existence of parenthood ex lege is that the existence of parenthood does not depend on action by one of the persons involved. An example of ex lege existence of parenthood is the existence of parenthood under English law. Under English law, the genetic father is the legal father by dint of being the genetic father of the child. It is not necessary to establish his paternity. This is also why legal maternity under French law never exists ex lege. After all, under French law one must at least mention the mother's name on the birth certificate before she will be considered to be the child's legal mother, which requires an official action (Article 311-25 French Civil Code). Legal maternity does not exist by dint of birth. The fact that Article 310-1 French Civil Code states that legal affiliation is established by operation of law (par l'effet de la loi) does not alter this proposition. ${ }^{55}$

\footnotetext{
${ }^{55}$ It must be realised that under French law registration is not considered to be a constitutive element of the establishment of legal maternity. In the French perspective legal maternity therefore does not follow from the registration of the mother's name on the birth certificate. It follows from the law, since the law provides explicitly that legal maternity follows from registration (Article 311-25 French Civil Code). Without that provision, the registration of the mother's name would - according to French law have no consequence for the legal affiliation of the child. Registration of maternity is therefore from
} 
In the case of existence of parenthood ex lege, action is only required in order to create proof of the legal situation which has come about automatically; persons involved have to register the child as their own. However, in case of ex lege existence of parenthood, the legal parenthood does not depend on the registration; it also exists without the registration.

The consequence of ex lege existence of parenthood is that legal parenthood usually corresponds with the national ground of legal affiliation. In the typical case the law will state something like: $\mathrm{X}$ is the parent of the child (e.g. the woman who gives birth to the child is the child's mother, the man who consents to the artificial insemination is the child's father etc.). The consequence of such a system of ex lege attribution of parenthood is that a legal system does not provide for a procedure for annulment of parenthood, since there is nothing to annul. This is only different in case of marital paternity, i.e. paternity which exists on the basis of marriage of the man with the child's legal mother (see below).

In the countries under consideration we find ex lege existence of parenthood at various places in the law. First of all, existence of parenthood under English law is, as has been stated above, always ex lege, also if it concerns paternity out of wedlock. Thus under English law the birthmother is automatically the child's legal mother and the genetic father is automatically the child's legal father in cases where the Human Fertilisation and Embryology Act does not apply. If the Human Fertilisation and Embryology Act applies and if the conditions of section 28 of that Act are fulfilled, the consenting partner will automatically be the child's legal father.

How do we know this? It should be noted that under English law parenthood in case of natural reproduction is a matter of common law and as such it has not been codified. Thus, there is no statute which says something like 'the genetic father of the child is his or her legal father'. Moreover, the proposition that parenthood exists ex

the French perspective not the same as acknowledgment of maternity. In case of acknowledgment of maternity, the legal maternity follows directly from the acknowledgment.

From a comparative perspective however registration and acknowledgment under French law are the same. It does not matter very much whether one says that legal maternity follows from the law, but the law requires registration, or whether one states that the law provides for a possibility of acknowledgment of maternity as a result of which legal maternity is established. In both cases, the existence of legal maternity depends on legal action being taken. Moreover, there is a fundamental difference between the French idea that legal maternity is established by operation of the law if the mother's name is registered as such, and, for example, the Dutch or German idea that even if the mother is not registered, she will be the child's legal mother. This is especially so if one realises that under French law, the registration of the mother's name is at her discretion; it is up to the mother whether or not she wants her name to be mentioned on the birth certificate (Article 326 French Civil Code). 
lege is a typical continental way of stating the law. An English lawyer will not use this terminology, because the fact that, for example, legal paternity exists ex lege, does not have the consequence that the genetic father will have parental responsibility. Outside of marriage, the fact that the man is the child's genetic father at least has to be registered before he has parental responsibility. ${ }^{56}$

The reason why it is still important to consider the alleged ex lege existence of paternity under English law is because continental law makes a clear distinction between, on the one hand, establishment of parenthood and, on the other hand, the consequences of parenthood. The method of establishing legal parenthood is a big issue in continental legal systems, judging from the huge piles of legal writing which are dedicated to this issue. The argument for ex lege existence under English law goes as follows. Let us take for example section 10 Births and Deaths Registration Act 1953. It provides:

Notwithstanding anything in the foregoing provisions of this Act [and subject to section 10ZA of this Act], in the case of a child whose father and mother were not married to each other at the time of his birth, no person shall as father of the child be required to give information concerning the birth of the child, and the registrar shall not enter in the register the name of any person as father of the child except [...].

The provision provides that the unmarried 'father' of the child will not be registered, unless certain conditions are fulfilled. Obviously one wants to know who is meant with the 'father'. Under legal systems like the French or the German, the word would mean legal father and on the basis of the provisions in the Civil Code one would investigate who is the child's legal father. In case of an unmarried father one will find that there is no legal father, unless someone acknowledged paternity. It follows that continental legal systems put forward a formal concept of legal parenthood: parenthood does not depend on a material fact such as genetic affiliation or intention, but on a formality such as marriage or a formal procedure such as acknowledgment. However, English law does not have such rules. ${ }^{57}$ Under English law, parenthood is

\footnotetext{
${ }_{57}^{56}$ Section 4 Children Act 1989 (inserted by section 11 Adoption and Children Act 2002).

${ }^{57}$ For certain specified areas of law English law provides for a definition of paternity, like for nationality law (section 50 (9) British Nationality Act 1981).
} 
defined substantially, i.e. with reference to material facts. The first sentences in the part on fatherhood from a leading textbook on family law state:

With four exceptions, the law recognises the child's biological father as his legal father. First, if the parents are married any child born to the wife is presumed to be the child of the couple. $[\ldots]^{58}$

The presumption of legitimacy which is mentioned in the citation is only a rule of evidence which is used in court proceedings on legal affiliation. And even in such proceedings it is a very weak presumption. In $\operatorname{Re} F$ (a minor) it was formulated as follows:

That means that the presumption of legitimacy now merely determines the onus of proof. Once evidence has been led it must be weighed without using the presumption as a make-weight in the scale for legitimacy. So even weak evidence against legitimacy must prevail if there is no other evidence to counterbalance it. The presumption will only come in at that stage in the very rare case of the evidence being so evenly balanced that the court is unable to reach a decision on it. ${ }^{59}$

Formally the presumption of legitimacy also exists in case of registration of paternity, but it is easily rebutted. The Handbook for Registration Officers instructs registration officers as follows:

In space 4 the registrar must enter the name and surname (in block capitals) of the father where he is married to the child's mother at the time of the birth. The registrar should ask: 'What was the full name and surname of the child's father at the date of the birth?' When the informant is the mother particular care should be taken to avoid asking for the information by a question such as 'What is your husband's name?'.60

\footnotetext{
${ }^{58}$.M. Cretney e.a., Principles of Family Law, London: Sweet \& Maxwell (2003), p. 524. See also N. Lowe \& G. Douglas, Bromley's Family law, Oxford University Press (2007), p. 321.

${ }^{59}$ [1993] 3 WLR 369, (1993) 143 NLJ 472, [1993] Fam. Law 407.

${ }^{60}$ Handbook for Registration Officers, p. B2.20-23c, par. 21, 22 (last update 1/1994/P1).
} 
It turns out that if there is a father who has to be registered, it is the genetic father of the child. This becomes very clear if we continue reading the instructions for the registration officer:

Under the Perjury Act 1911, a person is guilty of an offence if he/she wilfully gives a false answer to any question put by a registrar of births and deaths relating to the particulars required to be registered, or deliberately gives to the registrar false information about a birth or death, or makes a false statement with the intent to have it inserted in a register of births or deaths. In these circumstances the informant should state the facts which he/she considers to be true, and should not state that the mother's husband is the father of the child if it is known that he could not have been (eg by reason of his death or continuous absence from her over a long period). The informant would be committing an offence if he/she gave information for the registration of the birth as that of the child of the mother and her husband knowing that in fact, her husband was not the child's father. But see also para $31 \mathrm{a}^{61}$

It follows that the presumption of legitimacy has hardly any relevance any more under English law. The above also shows that references to father or mother are apparently references to the father and mother at common law or under the Human Fertilisation and Embryology Act. Hence, at common law and under the Human Fertilisation and Embryology Act, the father and mother are defined substantially (i.e. with reference to material facts on which parenthood is based) and not formally (i.e. with reference to a certain procedure which has conferred the status of legal parent on the person involved) as is the case under continental law. Consequently, if the method of establishing parenthood under English law has to be qualified, it has to be qualified as existence of legal parenthood ex lege.

The consequence of the fact that parenthood exists ex lege under English law is that English law does not have a procedure equivalent to the continental procedure of acknowledgment. The registration of paternity under English law strongly resembles acknowledgment of paternity, but it does not create legal affiliation, as continental law acknowledgment does. Moreover, English law also does not have a

${ }^{61}$ Handbook for Registration Officers, p. B23-d-31, par. 28 (last update unknown). 
judicial procedure for establishment or annulment of legal affiliation, since obviously there is nothing to establish or to annul. English law only provides for a procedure to obtain a declaration of parentage, which is enough. ${ }^{62}$ Functionally a declaration of parentage is the same as a continental judicial procedure for establishment or annulment of parenthood but again, the big difference is that under continental law those procedures affect the legal reality, while under English law the legal reality remains the same, but its appearance changes. It follows that English law on legal affiliation is based almost exclusively on evidence. This will be discussed more in detail below under 'evidence'.

Parenthood also exists ex lege under continental legal systems. Legal maternity under Dutch and German law exists ex lege. Under both legal systems, the birthmother is the legal mother of the child solely by dint of the fact that she gave birth to the child. ${ }^{63}$ Under Swedish law it is uncertain whether legal maternity exists ex lege or whether it depends on registration. The Children and Parents Code (1949:381) does not give an answer and neither does Swedish literature. ${ }^{64}$ Legal maternity under French law does not exist ex lege, but depends on the registration of the mother's name on the child's birth certificate. ${ }^{65}$

Another part in the law on legal affiliation where we find ex lege existence of parenthood is the rule that the mother's husband is the child's legal father. This rule exists under all legal systems under consideration, except under English law. ${ }^{66}$ The reason why the existence of the legal paternity of the mother's husband is ex lege is because his paternity does not arise from any action. It only arises from the existence of the legal maternity of the man's spouse and his marriage to her.

From a systematic point of view it is important to realise that a legal system which provides for parenthood existing ex lege has one major problem and that is evidence. Although the parents and the child involved acquire their status immediately, they do not immediately have a means to prove their status in society. A

\footnotetext{
${ }^{62}$ Section 55A Family Law Act 1986 (inserted by the Child Support, Pensions and Social Security Act 2000).

${ }^{63}$ Germany: Article 1591 German Civil Code; the Netherlands: Article 1:198 Dutch Civil Code.

${ }^{64}$ For a discussion of legal maternity in Swedish law see: T. Tolstoy Kongstad, Mater simper certa est? En discussion kring moderskappresumtionen i svensk rätt och behovet av lagreglering rörande rättsligt moderskap, Examsarbete Juridiska Fakulteten vid Lunds Universitet (2003).

${ }^{65}$ Article 311-25 French Civil Code.

${ }^{66}$ Article 312 French Civil Code; Article 1592 (1) German Civil Code; Article 1:199 Dutch Civil Code; Article 1:1 Swedish Children and Parents Code (1949:381). On the presumption of legitimacy under English law see supra.
} 
registration system generally does not guarantee that the evidence of a legal affiliation (the birth certificate) represents the legal reality. This introduces legal uncertainty in the registers of civil status, something of which especially continental lawyers are not fond. A solution to this problem is to make legal parenthood dependant on an administrative action which produces tangible evidence of the legal relationship it creates. In that case there will be greater certainty that the birth certificate (or any other document meant to prove legal affiliation) correctly represents the legal situation.

\subsubsection{Establishment of parenthood by means of administrative action}

It is submitted that in every case in which the existence of legal parenthood depends on an official action taken by the persons involved and thus does not exist ex lege, it has to be established. Establishment of parenthood can be done by an administrative authority or by a court (judicial establishment of parenthood). Judicial establishment of parenthood will be discussed in the next paragraph.

From the national legal systems under consideration we can derive three kinds of administrative action which establish legal parenthood or which are at least mandatory in order to establish legal parenthood: registration of the parents on the child's birth certificate, acknowledgment of parenthood and the procedure to obtain an affidavit recording to apparent status of the child.

Establishment of parenthood through an administrative action has three important characteristics. First of all, the existence of legal affiliation depends upon the action of the persons involved; no legal relationship exists before the registration or the acknowledgment, unlike in case of parenthood which arises ex lege. Secondly, and contrary to ex lege existence of legal parenthood, the establishment of legal parenthood through an administrative action immediately creates proof of legal parenthood. It has already been explained above that a system in which the establishment of legal parenthood immediately produces the document which is meant to prove the legal parenthood enhances legal certainty. The final characteristic is the registrar's role in case of registration or acknowledgment. Although the precise function and powers of the registrar vary from country to country, the main task of a registrar is to register the facts declared to him by the persons involved. Unlike a judge, a registrar usually has little power to investigate the truth of the declarations of the persons before him. Notwithstanding the similarities between administrative 
actions for establishment of legal parenthood, it is important to keep them apart because the rules on annulment of legal parenthood are usually different.

A separate consequence of a system which obliges persons to establish legal affiliation is that such a system allows for more flexibility. By disconnecting the grounds for legal affiliation from the process of establishment of affiliation, a legal system has the possibility to create rules which allow deviation from the grounds of legal affiliation. Under French law for example, legal maternity does not exist ex lege, but it depends on the registration of the mother's name on the child's birth certificate. ${ }^{67}$ The mother is however not obliged to register her name; she has the right to give birth anonymously (accouchement sous X). ${ }^{68}$ Since the whole idea of anonymous birth is that the birthmother does not become the child's legal mother, it makes sense that a legal system does not provide for ex lege existence of legal maternity, if it wants to grant women the right of anonymous birth and thus wants to allow a certain flexibility as to the ground for legal affiliation (i.e. childbirth).

In the legal systems under consideration, only French law requires registration in order to establish the existence of parenthood. Also the procedure to obtain an affidavit which records the apparent status of the child only exists in France, ${ }^{69}$ and therefore it will not be discussed extensively here.

The third administrative procedure to establish legal parenthood is acknowledgment. Acknowledgment of parenthood exists under all legal systems under consideration, except under English law. ${ }^{70}$ The English functional equivalent of acknowledgment - registration of the unmarried father - will be discussed under the heading of evidence. The common ground in the institutions of Anerkennung, reconnaissance, erkenning and bekräftelse is that they are considered a legal act within their legal system (Rechtsgeschäft, acte juridique, rechtshandeling,), meaning that legal parenthood is established by virtue of an expression of the acknowledger's will, manifest in a legal act. The fact that the validity of the acknowledgment depends on the acknowledger's will does not mean that intention is the ground for legal parenthood that follows from the acknowledgment. An acknowledgment raises a presumption that the acknowledger is the genetic father or - depending on the legal

\footnotetext{
${ }^{67}$ Article 311-25 French Civil Code.

${ }^{68}$ Article 326 French Civil Code.

${ }^{69}$ Article 317 French Civil Code.

${ }^{70}$ Article 1594 - 1598 German Civil Code; Article 316 French Civil Code; Article 1:204 Dutch Civil Code; Article 1:4 Swedish Children and Parents Code (1949:381).
} 
system involved - the consenting partner. This is shown by the fact that acknowledgment can be annulled if the acknowledger is not the genetic father or the consenting partner. The acknowledger's will has nothing to do with the substantive aspects of the acknowledgment; it is only a formal part of the acknowledgment. The importance of the acknowledger's will is the result of the systems of law in which the acknowledgment exists. Dutch, French, German and Swedish civil laws are built around the concept that legal consequences follow from a legal act, which, in order to be valid, has to be the expression of the will, which at its turn must have been formed freely. If the will is defective because of threat, mistake or deceit the legal act is null and void and if the legal act is valid it can be annulled in the way prescribed by law. ${ }^{71}$ It is submitted that the importance of the acknowledger's will in civil law systems is a result of the legal system where it is used: the continent had a system of civil law which was built around the concept of legal act and the system to establish legal parenthood had to fit in that system.

An important consequence of acknowledgment as a system for attribution of legal parenthood is that legal parenthood can exist even if it is not in conformity with the ground for legal parenthood in the legal system involved, because the validity of the acknowledgment does not depend on the substantive truth, but on its formal validity. The degree to which this is considered to be a problem varies from country to country: in Sweden the discrepancy between the existance or legal parenthood and the ground on which it is founded was considered unacceptable and therefore Swedish law provides for a system in which an acknowledgment cannot be valid without the consent of the Socialnämnd (social welfare commission). The Socialnämnd will only consent to the acknowledgment if it is convinced that the acknowledger is the child's genetic father (or if he consented to the fertility treatment). ${ }^{72}$ At the other side of the spectrum is French law which does not have any problems with substantive truth. Also under French law, acknowledgment of paternity raises the presumption that the man is the child's genetic father, but no one will check the truth. After a certain period of time it even becomes impossible to apply for annulment of acknowledgment.

\subsubsection{Judicial establishment of parenthood}

\footnotetext{
${ }^{71}$ Some legal systems provide that annulment of acknowledgment because of a defective will is not possibile. However, that is then an exception to the general rule that legal acts can be annulled because of a defective will.

${ }^{72}$ Article 1:4 Swedish Children and Parents Code (1949:381).
} 
Judicial establishment of parenthood is a judicial procedure by which the court establishes legal parenthood upon proof of the existence of a ground for legal affiliation (genetic affiliation, intention or apparent status). ${ }^{73}$ Judicial establishment of parenthood is only possible if the child does not yet have a parent from both sexes (or under Swedish law, if the lesbian partner did not acknowledge maternity). Therefore judicial establishment of legal maternity is not possible in countries in which legal maternity exists ex lege. Since judicial establishment of parenthood creates a legal relationship, a declaration of parentage under English law is not judicial establishment of parenthood although it is its functional equivalent. Declarations of parentage will be explained under the heading of evidence.

The characteristics of judicial establishment of parenthood are the inverse of establishment of parenthood by an administrative action. So, it is pretty sure that parenthood will only be attributed in conformity with the ground for legal parenthood. Moreover, the national authority involved has extensive competence to investigate whether the applicant or the respondent is the child's father or mother.

Legal systems on judicial establishment of parenthood differ in various respects. The most important difference concerns the rules on the use of DNA evidence. This will be discussed below under evidence. Other differences concern the exceptions to the ground of legal affiliation, the locus standi and the statutory periods of limitation.

\section{a. Exceptions to the grounds of legal affiliation}

The general rule under the legal systems under consideration is that the court will establish legal parenthood if the existence of a ground for legal affiliation is proven. Hence, the establishment of the spermdonor as a parent is prohibited under all legal systems except under German law. ${ }^{74}$ There are a couple of exceptions to this rule. First of all, regarding Dutch law it has been stated that only genetic affiliation is a ground for legal affiliation. However, according to Article 1:207 Dutch Civil Code, the man, who consented to the act which could have resulted in the procreation of the child can also be established to be the child's father, if he was the mother's partner.

\footnotetext{
${ }^{73}$ Article 1600d German Civil Code; Article 325 - 331 French Civil Code; 1:207 Dutch Civil Code; 1:5 Swedish Children and Parents Code (1949:381).

${ }^{74}$ English law: Section 28 (6) Human Fertilisation and Embryology Act; French law: Article 311-19 French Civil Code; Swedish law: Article 1:5 Swedish Children and Parents Code (1949:381). Dutch law see note 75 below. German law: BT Drucks. 12/2091, in which the government answers the question to what extent the anonymity of the sperm donor is protected. See also Münchener Kommentar zum BGB Volume 8/Seidel (2002), p. 69.
} 
This provision should be considered together with the provision that under Dutch law only the child and the mother can apply for judicial establishment of paternity. The reason for this rule is primarily to protect the mother's interest: it was deemed unacceptable that if the mother and her partner decided to obtain fertility treatment with donor semen, the partner could escape his responsibilities by not acknowledging paternity. Also the child's interest in having a legal father played an important role. The establishment of the legal paternity of the anonymous sperm donor is for the same reason prohibited under Dutch law. ${ }^{75}$ While, on the one hand, the interests of the mother and child are honoured by giving them a possibility to apply for judicial establishment of paternity, the consenting partner's interest (i.e. his intention to become the legal parent) is, on the other hand, not protected, which indicates that intention is still not a ground for legal affiliation under Dutch law. After all, in case of marital paternity the legal presumption of paternity in favour of the mother's husband is susceptible to annulment on application by the child ${ }^{76}$ and in case of assisted reproduction out of wedlock the consenting partner can only establish that he is the child's father with the mother's consent. ${ }^{77}$

The second exception to the rule that legal parenthood will be judicially established if the existence of a ground for legal affiliation is proved is that under Dutch and French law, the establishment of legal affiliation with both parents is not possible in case of an incestuous relationship between the father and the child's

\footnotetext{
${ }^{75}$ Under Dutch law one can only judicially establish the legal paternity of the consenting partner or the begetter. The anonymous sperm donor is neither of these two persons. See also J. de Boer, Asser's Personen en Familierecht, Deventer: Kluwer (2002), p. 499.

${ }^{76}$ Article 1:200 (1) Dutch Civil Code.

77 Under Dutch law, legal paternity of the consenting partner can be established by means of acknowledgment of paternity and by means of judicial establishment. The consenting partner has no standing to apply for judicial establishment of his legal paternity (Art. 1:207 Dutch Civil Code) and acknowledgment of paternity requires the mother's consent (and the child when the child has reached the age of twelve) (art. 1:204 (1) under $\mathrm{c}$ and d Dutch Civil Code). If the man is the begetter of the child, he can apply for substitution of the mother's consent on the basis of Article 1:204 (3) Dutch Civil Code, if she refuses to consent to his acknowledgment. However, the consenting partner is usually not the begetter of the child, since the begetter is the man who begot the child via sexual intercourse. Consequently, the consenting partner has no direct right of action under the Civil Code to apply for substitution of the mother's consent. So far the Dutch Supreme Court has not been asked to rule upon the legality of this situation. In a case where a sperm donor (also not a begetter) applied for substitution of the mother's consent, the Dutch Supreme Court held that the mother's consent could only be replaced by judicial consent if the donor could show that the mother's refusal amounted to an abuse of her right to give consent (HR 24th January 2003, NJ 2003/386). An important difference between the sperm donor and the consenting partner is that the former, but not the latter, is the child's genetic father.
} 
mother. ${ }^{78}$ Under those legal systems it is deemed not to be in the child's interest to have the incestuous relationship recognised in law. ${ }^{79}$

\section{b. Locus standi}

The right to apply for judicial establishment of parenthood is restricted under all legal systems under consideration. The reason to restrict the locus standi of this action is its personal nature. Within the legal systems involved, there are two groups of persons who have standing: the persons directly involved (the child, the mother and the father) and their heirs.

With regard to the locus standi of the persons who are directly involved in the action, most legal systems provide an unrestricted right for the child and a restricted or dependant right for the mother. Only under German law do the child, the mother and the alleged father have the right to apply for judicial establishment of paternity on an equal footing. ${ }^{80}$ Under Dutch law the child has an unrestricted right to apply for judicial establishment of paternity, but during the child's minority he or she is represented by a special representative (bijzondere curator). ${ }^{81}$ The mother's right to apply for judicial establishment is restricted by a statutory period of limitation: she has to apply within five years from the child's birth or within five years from the moment at which she knows who the begetter of the child is. ${ }^{82}$ Under French law, only the child has the right to apply for judicial establishment of maternity or paternity. ${ }^{83}$ However, during the child's minority only a person established to be a legal parent of the child has the right to apply on the child behalf. ${ }^{84}$ Swedish law provides more or less the same. The child has the right to apply for judicial establishment of paternity, but during the child's minority the Socialnämnd or the mother have the right to exercise the right. ${ }^{85}$ Since it will be argued below that the English declaration of parentage is the functional equivalent of judicial establishment

\footnotetext{
${ }^{78}$ Article 1:207 (2) under b Dutch Civil Code; Article 310-2 French Civil Code.

${ }^{79}$ France: F. Dekeuwer-Defossez e.a. Rénover le droit de la famille: propostions pour un droit adapté aux réalités et aux aspirations de notre temps, Paris: La documentation Française (1999), p. 45. The Netherlands: Second Chamber, 1995-1996, 24 649, nr. 3, p. 19 (explanatory notes).

${ }^{80}$ Article $1600^{\mathrm{e}}$ German Civil Code. See also Staudinger's Kommentar zum BGB, Part IV/Rauscher, Berlin: Sellier - de Gruyter (2004), p. 525.

${ }^{81}$ Article 1:212 Dutch Civil Code.

${ }^{82}$ Article 1:207 (3) Dutch Civil Code.

${ }^{83}$ Articles 325 and 327 French Civil Code.

${ }^{84}$ Article 328 French Civil Code.

${ }^{85}$ Article 3:5 Swedish Children and Parents Code (1949:381).
} 
of parenthood, it is worth mentioning that under English law everyone with sufficient personal interest can apply for a declaration of parentage. ${ }^{86}$

The second group which has locus standi to apply for judicial establishment of parenthood are the heirs of the persons who are directly involved and who have a right to apply. Under German and Swedish law the heirs or the descendants do not have a statutory right to apply for judicial establishment of paternity after the child's death. Under Dutch law however, the descendants in the first degree(afstammelingen) of the child $(\mathrm{X})$ are allowed to apply for judicial establishment of the fact that a man $(\mathrm{Y})$ is the father of their deceased parent $(\mathrm{X})$. However, their right is restricted: they only have that right if the alleged father $(Y)$ is still alive and on condition that the right is exercised within one year after learning of the death of their parent $(\mathrm{X}) .{ }^{87}$ The mother's descendants have no such right. Under French law, more or less the same rule applies. Not, as in Dutch law, the descendants, but the broader group of heirs have the right to exercise the right to apply for judicial establishment of paternity if the deceased died before expiry of the statutory period of limitation. ${ }^{88}$ For judicial establishment of parenthood this means that the X's heirs can apply for judicial establishment of $\mathrm{Y}$ as $\mathrm{X}$ 's father, if $\mathrm{X}$ died before the ending of the statutory period of limitation, which is ten years after $\mathrm{X}$ has come of age in case of judicial establishment of parenthood. ${ }^{89}$

\section{c. Statutory periods of limitation}

In certainly not for the child. This is only different under French law where the child has to apply within ten years after he or she has come of age. ${ }^{90}$ Moreover, under Dutch and Swedish law the mother's right (and the Socialnämnd) is restricted in time. Under Dutch law, the mother has to apply within five years after she becomes aware of the identity of the begetter ${ }^{91}$ and under Swedish law the Socialnämnd and the mother can only apply during the child's minority. ${ }^{92}$ Under German law, the right to apply for judicial establishment of paternity is not restricted in time for any of the

\footnotetext{
${ }^{86}$ Section 55a (3) Family Law Act 1986.

${ }^{87}$ Article 1:207 (4) Dutch Civil Code.

${ }^{88}$ Article 322 French Civil Code.

${ }^{89}$ Article 321 French Civil Code.

${ }^{90}$ See note 89.

${ }^{91}$ See note 82 .

${ }^{92}$ See note 85 .
} 
applicants. Even after the child has come of age, the alleged father and the mother have a statutory right to apply for judicial establishment of paternity. ${ }^{93}$

\subsubsection{Annulment of parenthoodgeneral the right to apply for judicial establishment of parenthood is not restricted in time,}

Annulment of legal parenthood is a mechanism which provides for the possibility to bring legal parenthood in conformity with the grounds for legal affiliation. ${ }^{94}$ Therefore, procedures for annulment of legal parenthood only exist in legal systems which have a system of attribution of parenthood which does not guarantee that legal parenthood is in conformity with the grounds for legal affiliation. Annulment of parenthood which exists ex lege is usually not possible. The only exception to this rule within the systems under consideration is the procedure for annulment of paternity arising form the presumption of paternity by dint of marriage with the child's mother.

Procedures for annulment of legal parenthood are always restricted and there are a lot of possible restrictions: locus standi, statutory periods of limitation and additional requirements such as lack of capacity at the moment of acknowledgment or the absence of apparent status. Also the rules on evidence restrict the possibility of annulling legal parenthood under certain legal system. Reasons which have been advanced for these restrictions are the protection of the legal family or the private life of the persons directly involved (restrictions on locus standi), stability of the legal affiliation status of the child (statutory periods of limitation, existence of a lack of capacity at the moment of acknowledgment), preservation of de facto family, of social reality (requirement of the absence of apparent status). These reasons will be discussed in more detail below. Here, it should be noted, in the light of the discussion on Article 8 ECHR below, that these reasons or interests can be formulated as public and private interests. For example, the reason for statutory periods of limitation usually is to protect the stability of the legal affiliation status. Stability of affiliation status is in the state's interest, in particular in the maintainance of a reliable state administration, but it is also in the child's interest because the development of a close personal relationship is supported by the measure. It will be explained below that when in a concrete case certain restrictions do not protect any private interest any

\footnotetext{
${ }^{93}$ Staudinger's Kommentar zum BGB, Part IV/Rauscher, Berlin: Sellier - de Gruyter (2004), p. 530.

94 This paragraph does not deal with the possibility which exists in France to declare an acknowledgment null and void because of a defective will.
} 
more - for example, all the parties directly involved agree that notwithstanding the expiration of the statutory period of limitation the legal paternity should be annulled it is more likely that the restriction will violate Article 8 ECHR.

Before we embark on a detailed analysis on the regulations on annulment of legal parenthood, two preliminary remarks on the structure of these regulations have to be made. First, in most cases annulment of legal parenthood can only be done by a court; one needs to follow a judicial procedure. However, under certain circumstances some legal systems allow for administrative annulment of parenthood. Second, some legal systems have a regulation for annulment of parenthood which applies to all forms of establishment of legal parenthood but there are also legal systems which have separate provisions for the annulment of legal parenthood according to the form of establishment. In the following analysis judicial procedures for annulment of parenthood will first be discussed, followed by the administrative procedures. The legal systems under consideration do not provide for a possibility to annul legal parenthood which is based on judicial establishment. The possibility to set aside judicially established legal parenthood in a revision procedure falls outside the scope of this article.

\section{a. Judicial annulment of legal parenthood}

Judicial annulment of maternity is only possible in France. Under Dutch, English and German law legal maternity exists ex lege and therefore annulment of legal maternity is not possible. Of course it is possible under these legal systems that another woman than the birthmother is registered on the birth certificate and obviously there are procedures to change the birth certificate in such a case. However, those procedures are not procedures for annulment of legal maternity. They only concern the registration of legal maternity and therefore they will be discussed under the heading of evidence. The procedure for annulment of legal maternity in France is the same as for legal paternity, so no separate reference will be made as to whether the procedure concerns the mother or the father.

The ground for annulment of legal parenthood in all legal systems is that legal affiliation does not correspond with the ground for legal affiliation which applies in the situation at hand. ${ }^{95}$ So, the ground for annulment of legal paternity in Germany and the Netherlands is that the legal father is not the genetic father of the child. In

\footnotetext{
${ }^{95}$ See $\S 1.2$. Grounds for legal affiliation. See note 21 for an overview of the national provisions on annulment of legal parenthood.
} 
Sweden the grounds are that the man is not the genetic father or that the parent did not (validly) consent to the fertility treatment. In France, one adds the absence of apparent status. ${ }^{96}$ This paragraph will mainly focus on the different restrictions which are imposed on the possibility to apply for judicial annulment of parenthood. They are discussed under the headings of apparent status, locus standi and statutory periods of limitation. However, we will start with a separate discussion of the list of additional restrictions on the possibility to apply for annulment of legal paternity which only exist under Dutch law.

\section{b. Restrictions on judicial annulment of paternity under Dutch law}

Apart from the restrictions on annulment of legal paternity which will be discussed under the following headings, Dutch law contains a set of restrictions which are not found in the other legal systems. It concerns restrictions on the possibility to annul marital paternity and paternity established by means of acknowledgment of paternity.

The legal parents cannot annul marital paternity under Dutch law if the man knew before the marriage that the woman was pregnant ${ }^{97}$ or if the man consented to the act which could have resulted in the procreation of the child. ${ }^{98}$ These exceptions do not apply if the woman has deceived the man as to who has conceived the child. ${ }^{99}$ The raison d'être of the consent-exception has already been discussed above. ${ }^{100}$ The reason behind the first exception is that according to Dutch law, marriage with a pregnant woman is considered a tacit acknowledgment of paternity. ${ }^{101}$ This somewhat archaic justification also explains the exception to the exception: if the woman deceived her husband as to the paternity of the child he would probably not have married her in the first place (continuing the archaic line of reasoning), so he should at least be allowed to annul his paternity. Although the justification does not sound ultra

\footnotetext{
${ }^{96}$ Article 335 French Code Civil.

${ }^{97}$ Article 1:200 (2) Dutch Civil Code.

${ }^{98}$ Article 1:200 (3) Dutch Civil Code.

${ }^{99}$ Article 1:200 (4) Dutch Civil Code.

${ }^{100} \S \mathrm{a}$ a. Exceptions to the grounds of legal affiliation.

101 Article 1:200 (2) Dutch Civil Code is almost a literal copy of Article 314 French Civil Code 1804. The reason for this article is formulated as follows: "On présume alors qu'il n'a contracté le mariage que pour réparer sa faute personnelle; on présume qu'un pareil hymen n'eut jamais été consenti, s'il n'eût persuadé que la femme portait dans son sein le fruit de leurs amours : et lorsqu'il a eu dans la conduite de cette femme une telle confiance qu'il a voulu que leurs destinées fusses unies, comment pourrait-on l'admettre à démentir un pareil témoignage?" (Motifs des lois du code civil des français, promulguées en l'an XI et l'an XII, Tome Premier, De l'imprimerie nationale (Paris, an XII, 1804), p. 147).
} 
modern, one has to point to the similarity with acknowledgment of paternity, which is also very hard to annul. ${ }^{102}$

The deceit-exception also applies to the consent-exception. Therefore, if the married couple agrees that the woman will have sexual intercourse with $\mathrm{X}$ in order to get a child, but secretly the woman has intercourse with $\mathrm{Y}$, the husband is allowed to apply for annulment of his paternity. ${ }^{103}$

Also with regard to annulment of acknowledgment of paternity Dutch law provides for additional requirements. First of all, Article 1:205 (1) Dutch Civil Code provides that the child can only apply for annulment of legal parenthood on the basis of acknowledgment if the acknowledgment took place during his or her minority. If the acknowledgment took place during the child's minority, the child can apply without further restrictions for annulment of legal parenthood within the prescribed period of limitation (see next paragraph). If the acknowledgment took place after the child has come of age, the child has no right to apply for annulment of legal paternity at all. The legal parents can only apply for annulment of legal parenthood based on acknowledgment if the acknowledgment or the consent to the acknowledgment has come about under the influence of threats, mistake, deceit or, if the acknowledgment was done during the minority of the acknowledger or the mother, undue influence (bedreiging, dwaling, bedrog of misbruik van omstandigheden). The reason is that the establishment of legal affiliation was not considered something which the persons involved should be able to dispose of as they pleased. ${ }^{104}$

\section{c. Judicial annulment of legal parenthood and apparent status}

The meaning of apparent status has already been explained briefly above. ${ }^{105}$ It has also been explained that the function of apparent status is diverse. Under French law, it is, for example, a ground for legal affiliation, but the concept is also used for other purposes under French and Dutch law. Under both legal systems the existence of apparent status in conformity with the title of legal affiliation (i.e. the birth certificate or the instrument of acknowledgment of parenthood) limits the possibility of annulling legal affiliation. Thus under Dutch law legal affiliation can only be annulled if the child has apparent status with regard to the parent who is mentioned on the birth

\footnotetext{
${ }^{102}$ J. de Boer, Asser's Personen en Familierecht, Deventer: Kluwer (2002), p. 507.

${ }^{103}$ Cf. J. de Boer, Asser's Personen en Familierecht, Deventer: Kluwer (2002), p. 509.

${ }^{104}$ Second Chamber, 1995/96, 24 649, nr. 3 (explanatory report), p. 10.

$105 \S 1.2 .1 .2$. Apparent status or possession d'état.
} 
certificate. ${ }^{106}$ This provision has potentially far-reaching consequences, although it is hardly used in practice. Article 1:209 Dutch Civil Code means for example that if a child develops apparent status with regard to the husband before the expiry of the statutory period of limitation in Article 1:200 Dutch Civil Code, the husband will not be able to apply for annulment of the paternity established by the presumption based on marriage to the child's mother. Even if the wrong mother is registered on the birth certificate and if the child develops apparent status with regard to her, it is not possible to correct the birth certificate! The reason for this provision is that established social relations should not be disrupted. ${ }^{107}$

Under French law the coexistence of apparent status with the title of legal affiliation has as a consequence that the statutory period to annul the legal affiliation which exists on the basis of the title shortens and that the locus standi is more limited. Thus, Article 333 French Civil Code provides that if the apparent status is in conformity with the title of legal affiliation, only the child, the legal parents and the alleged parents are allowed to apply for annulment of legal parenthood which is based on that title (i.e. a registration or an acknowledgment). Moreover, they have to act within 5 years after the apparent status has ceased to exist and before the apparent status and the title have coexisted for 5 years. If the title is not supported by apparent status, everyone with an interest is allowed to apply for annulment of legal parenthood within ten years after the title has been drawn up. ${ }^{108}$

\section{d. Locus standi}

Another important restriction on the possibility to annul legal parenthood is the presence or absence of locus standi. The main reason in all legal systems to provide for a restriction on the locus standi for annulment of legal parenthood is the protection of the legal family and the private life of the members of that family. ${ }^{109}$ This common idea does not prevent the legal systems involved from coming up with different regulations. Especially the right of the biological parent who is not the child's legal parent to apply for annulment of legal parenthood differs considerably. A second issue regarding locus standi is the right of the heirs to apply for annulment on behalf

\footnotetext{
${ }^{106}$ Article 1:209 Dutch Civil.Code.

${ }^{107}$ See note 15 .

${ }^{108}$ Article 334 French Civil Code.

${ }^{109}$ Germany: Münchener Kommentar zum BGB Volume 8/Seidel (2002), p. 171; France: J. Massip, Le nouveau droit de la filiation, Paris: Defrénois (2006), p. 64; The Netherlands: Second Chamber, 19951996, 24 649, nr. 3 , p. 18 (explanatory notes); Sweden: A. Singer, Föräldraskap i rättslig belysning. Uppsala: Iustus Förlag (2000), p. 167.
} 
or in the place of a deceased relative and the right of the public prosecutor to intervene on behalf of the public interest.

Under German law, the child and the legal parents have the right to apply for annulment of legal paternity. ${ }^{110}$ As will be explained below, the applicants' rights are not unrestricted: they are limited in time and the legal parents are not allowed to apply for annulment of legal paternity if they have consented to the assisted reproduction treatment. $^{111}$ The latter reason has been inserted by the Kinderrechtverbesserungsgesetz 2002. Notwithstanding German reluctance to allow assisted reproduction, the legislator wanted to provide for a minimum regulation to protect the child who has been conceived following fertility treatment with donor semen. ${ }^{112}$ Besides the members of the nuclear family also the alleged genetic father has a limited right to apply for annulment of legal paternity, following a decision of the German Constitutional Court in 2003. ${ }^{113}$ The right of the alleged genetic father is restricted though, in order to protect legal certainty and the legal family. ${ }^{114}$ Article 1600 (2) German Civil Code provides that the alleged genetic father is only allowed to apply for annulment of legal paternity if there is no social family relationship (sozial-familiäre Beziehung) between the legal father and the child. Such a relationship is presumed to exist if the legal father has brought the child up and if the legal father lived or lives together with the legal mother and child. ${ }^{115}$

French law has a separate regulation for annulment of legal affiliation which exists ex lege (i.e. marital paternity), either, on the one hand, on the basis of registration or acknowledgment, or, on the other hand, legal affiliation which exists on the basis of apparent status recorded in an affidavit. Locus standi for annulment of legal parenthood which exists ex lege or on the basis of registration or acknowledgment is more or less the same as under German law, but in French law there seem to be fewer problems in accepting the right of the alleged parent (father or mother) to apply for annulment of parenthood. Under French law the locus standi depends on whether the title for legal affiliation (i.e. the birth certificate or the instrument of acknowledgment) is supported by apparent status or not. If the title is supported by apparent status, which is usually the case, only the child, the legal

\footnotetext{
${ }^{110}$ Article 1600 (1) German Civil Code.

${ }^{111}$ Article 1600 (4) German Civil Code.

${ }^{112}$ BT Drucks. 14/2096, p. 7.

${ }^{113}$ BVerfG, 1 BvR 1493/96 of 9.4.2003.

${ }^{114}$ BT Drucks. 15/2253, p. 11.

${ }^{115}$ Article 1600 (3) German Civil Code.
} 
parents and the alleged parents have the right to apply for annulment of parenthood. ${ }^{116}$ If the legal affiliation which is based on registration or acknowledgment is not supported by apparent status, the legal affiliation can be annulled by everyone with sufficient interest. ${ }^{117}$ Locus standi to annul legal affiliation which exists on the basis of apparent status recorded in an affidavit can be annulled by everyone with sufficient interest. $^{118}$

Under Dutch and Swedish law the alleged parent is not allowed to apply for annulment of legal parenthood, although under Dutch law there is a possibility to circumvent this rule under certain circumstances. Under Dutch law, only the legal parents and the child have a statutory right to apply for annulment of marital paternity ${ }^{119}$ or paternity which exists on the basis of acknowledgment. ${ }^{120}$ Nonetheless, the biological father has a possibility to set aside the acknowledgment by another man under certain circumstances. In that respect one has to distinguish the case in which the biological father is the begetter of the child from the case in which he is the sperm donor. If the begetter wants to acknowledge paternity and if the mother refuses to consent, he can apply for judicial consent which will replace the consent of the mother. ${ }^{121}$ He will obtain judicial consent, unless it is shown that the establishment of his paternity is detrimental to the child's interests. Emotional resistance on the mother's part is not enough to refuse the begetter judicial consent. ${ }^{122}$ It is however possible that the mother consented to the acknowledgment of the child by another man. In that case the Dutch Supreme Court decided that the begetter's possibility to set aside the acknowledgment depends on whether the mother allowed the begetter the possibility to apply for judicial consent. ${ }^{123}$ If that is the case, i.e. if the begetter had enough time to apply for judicial consent following the refusal of the mother to consent, the court will only set aside the acknowledgment of the other man if the begetter shows that the mother's consent was given with no other reason than to harm his interests. If the mother did not allow the begetter enough time, the court will set

\footnotetext{
${ }^{116}$ Article 333 French Code Civil.

${ }^{117}$ Article 334 French Code Civil.

${ }^{118}$ Article 335 French Code Civil.

119 Article 1:200 (1) Dutch Civil Code. For limitations on the right of the legal parents to annul legal paternity see $\S$ b. Restrictions on judicial annulment of paternity under Dutch law

${ }^{120}$ Article 1:205 (1) Dutch Civil Code. For limitations on the right of the legal parents to annul legal paternity see $\S$ b. Restrictions on judicial annulment of paternity under Dutch law.

${ }^{121}$ Article 1:204 (3) Dutch Civil Code.

122 Dutch Supreme Court 13th April 2001, NJ 2001/464; Dutch Supreme Court 16th February 2001, NJ 2001/571.

${ }^{123}$ Dutch Supreme Court 12th November 2004, NJ 2005/248.
} 
aside the acknowledgment if the begetter shows that the mother could not have reasonably consented to the acknowledgment, taken into account the begetter's interests. There is no case law on the question whether the biological father has a possibility to set aside an acknowledgment, in the situation that the genetic father is not the child's begetter but the sperm donor. ${ }^{124}$

Under Swedish law only the child and the legal father have the right to apply for annulment of marital paternity. ${ }^{125}$ Swedish law does not have statutory provisions on locus standi for annulment of acknowledgment, but is generally accepted that only the legal father and the child have the right to apply for annulment of acknowledgment. $^{126}$

Besides the persons who are directly involved in the issue of legal affiliation, the heirs and the public prosecutor also have standing to apply for annulment of legal parenthood under certain circumstances. The applicant's heirs have standing to apply for annulment of legal parenthood, if the applicant died before the expiration of the period of limitation which applied to the applicant. They also have to bring their action within the period which applied to the decedent. ${ }^{127}$ Under Dutch law Article 1:201 Dutch Civil Code provides for a regulation which applies equally to annulment of marital paternity (based on the presumption arising from marriage to the child's mother) and paternity based on acknowledgment. The descendants, and if there are none, the spouse, and if there is no spouse, the parents of the legal parent, have the right to apply for annulment of parenthood if the legal parent died before the expiration of the period of limitation which applies to the deceased legal parent. They have to apply within one year after they are informed of the death of the legal parent. In case of the child, only the descendants of the child have the right to apply for annulment of legal paternity if the child died before the expiration of the period of limitation which applies to the child. If the child died after he or she has come of age,

\footnotetext{
${ }^{124}$ The Dutch Supreme Court ruled on the question whether a sperm donor can apply for judicial consent to his acknowledgment, if the mother refuses consent and if there is no acknowledgment yet. In that case, the Court held that the statutory regulation in Article 1:204 (3) Dutch Civil Code does not apply, since that provision only applies to the begetter. Accordingly the sperm donor can only obtain judicial consent if the mother has no other reason for her refusal than to harm the interests of the sperm donor (Hoge Raad 24th January 2003, NJ 2003/386).

${ }_{125}$ Article 3:1 and 3:2 Children and Parents Code (1949:381).

${ }^{126} \AA$ A. Saldeen, Karnov, Svensk lagsamling med kommentarer (tenth edition ed.), Stockholm: Thomson Fakta (2005/06), p. 372f, note 17; $\AA$. Saldeen, Barn- och föräldrarätt. Uppsala: Iustus Förlag (2005), p. 77; G. Walin, S. Vängby Föräldraskap. En Kommentar. Del I. 1-13 kap (with supplements), Stockholm: Norstedts Juridik (2001), p. 1:15; A. Singer, Föräldraskap i rättslig belysning. Uppsala: Iustus Förlag (2000), p. 196.

${ }^{127}$ Article 322 French Civil Code.
} 
the descendants have to apply within one year after they were informed of the child's death. If the child died during his minority, the descendants have to apply within one year after the moment the child would have come of age.

Finally, under French law the public prosecutor has the right to apply for annulment of legal parenthood if it appears from the register itself that the legal affiliation is not in conformity with the grounds for legal affiliation or in case of fraus legis. ${ }^{128}$ In Dutch law, the power of the public prosecutor is limited to legal affiliation on the basis of acknowledgment, if the acknowledger is not the child's begetter and if his acknowledgment violates Dutch public policy. ${ }^{129}$ A proposal is pending to introduce a similar possibility under German law. ${ }^{130}$

\section{e. Statutory periods of limitation}

As with the regulation on locus standi, the reasons why legal systems provide for statutory periods of limitation are usually the same, but that does not prevent considerable difference in outcome: we will see periods of limitation ranging from one to ten years. The main reason to provide for a time limit on the action for annulment of legal parenthood is to grant stability to the legal affiliation status of the child. Also the protection of family peace has been mentioned in this respect. ${ }^{131}$ Only Sweden has taken the step of abolishing the periods of limitation, since the protection of legitimacy was not necessary any more and it was deemed in the interest of both the father and the child to able to clarify the genetic affiliation at any time. ${ }^{132}$

Legal systems which provide for a period of limitation for annulment of legal parenthood differ as to the length of the period, but also as to the moment at which the period starts running. Under German law, the period of limitation is two years for all applicants. ${ }^{133}$ The period starts running at the moment the applicant is informed that the legal father is probably not the child's genetic father. For the alleged genetic father who is not the legal father this means that the period starts running against him as soon as he is informed that the legal father is not the child's genetic father.

\footnotetext{
${ }^{128}$ Article 336 French Civil Code.

${ }^{129}$ Article 1:205 (2) Dutch Civil Code.

130 D. Henrich, 'Zum Entwurf eines Gesetzes zur Ergänzung des Rechts zur Anfechtung der Vaterschaft', Zeitschrift für das gesamte Familienrecht (2006), p. 977-979.

${ }^{131}$ Germany: BR Drucks. 180/96, p. 97; BT Drucks. 13/4899, p. 87; Second Chamber, 1995-1996, 24 649, nr. 3, p. 17 (explanatory notes).

${ }_{132}$ Prop. 1975/76:170, p. 134; G. Walin, S. Vängby Föräldraskap. En Kommentar. Del I. 1-13 kap (with supplements), Stockholm: Norstedts Juridik (2001), p. 3:3 and 3:6.

${ }^{133}$ Article 1600b (1) German Civil Code.
} 
Whether he is also informed that he is probably the genetic father is irrelevant. ${ }^{134}$ Moreover, the period for the alleged father runs, even if there is a social family relationship within the meaning of Article 1600 (2) German Civil Code during which he is precluded from applying for annulment on the basis of that same article. The provisions are less severe for the child. If the legal paternity has not been annulled during the child's minority, he or she can apply for annulment within two years after he or she has come of age or at a later moment if the child is informed later that the legal father is probably not the genetic father. Moreover, Article 1600 (5) German Civil Code provides for a possibility to renew the period of limitation of the child if at any time the child is informed of facts which make the existence of legal paternity intolerable for the child, for example when the legal parents get divorced or when the legal mother marries the child's genetic father. ${ }^{135}$

Under Dutch law the period of limitation for annulment of legal paternity is one year for the legal parents and three years for the child. For annulment of marital paternity the period starts running for the mother at the moment of birth. ${ }^{136}$ For the legal father and the child the period starts running at the moment they are informed that the legal father is probably not the child's genetic father. ${ }^{137}$ If the child is informed during his minority, the period starts at the moment he or she comes of age. ${ }^{138}$ The regulation is the same for annulment of legal paternity based on acknowledgment. ${ }^{139}$ regarding the moment at which the period starts to run against the legal parents, Article 1:205 (3) Dutch Civil Code provides, regarding the moment at which the period starts to run against the legal parents, that the period starts running at the moment at which the threats, mistake or deceit are discovered or when the undue influence has stopped. ${ }^{140}$

Finally, under French law the length of the statutory period depends on whether or not the child has a title (e.g. a birth certificate) which is confirmed by apparent status (possession d'état). If the title is not confirmed by apparent status the

\footnotetext{
134 E. Höfelmann, 'Das neue Gesetz zur Änderung der Vorschriften über die Anfechtung des Vaterschaft und das Umgangsrecht von Bezugpersonen des Kindes', Zeitschrift für das gesamte Familienrecht (2004), p. 745 - 751, at p. 749; M. Wellenhofer-Klein, 'Das Vaterschaftsanfechtungsrecht des leiblichen Vaters - Vorslag zur Änderung von $\S 1600$ BGB', Zeitschrift für das gesamte Familienrecht (2003), p. 1889-1894, at p. 1893.

${ }_{135}$ Münchener Kommentar zum BGB Volume 8/Wellendorf-Klein (2002), p. 205.

${ }^{136}$ Article 1:200 (5) Dutch Civil Code.

${ }^{137}$ Article 1:200 (5) and (6) Dutch Civil Code.

${ }^{138}$ Article 1:200 (6) Dutch Civil Code.

${ }_{139}$ Article 1:205 (3) and (4).

${ }^{140} C f$. $\S$ b. Restrictions on judicial annulment of paternity under Dutch law.
} 
period starts running from the moment at which the child acquired the disputed status and the action has to be brought within ten years. ${ }^{141}$ If the title is confirmed by apparent status, there are two periods of limitation: ${ }^{142}$ the first period starts running at the moment the title is confirmed by apparent status and after five years the status becomes inviolable. However, if the apparent status ceases to exist before the end of the fifth year the action for annulment of marital paternity has to be brought within five years from the moment at which the apparent status has ceased to exist. In case of annulment of legal affiliation which exists on the basis of apparent status recorded in an affidavit, the period of limitation is five years from the moment at which the affidavit was drawn up. ${ }^{143}$

\section{f. Administrative annulment of parenthood}

Under Dutch, German and Swedish law it is possible to annul legal paternity which arises on the basis of marriage with the child's mother (the presumption of paternity) by an administrative procedure. The ground for annulment in such case is that it is unlikely that the husband is the child's genetic father, although the absence of genetic affiliation does not need to be proven.

Administrative annulment under Swedish and German law is only possible if at the same time another man acknowledges paternity. Swedish law offers the broadest possibility in that it is provided that marital paternity can always be annulled if someone else validly acknowledges parenthood. ${ }^{144}$ Valid acknowledgment in this context means that the mother and the Socialnämnd have consented to the acknowledgment and, in case of annulment of marital paternity, also the legal father himself. ${ }^{145}$ The consent of the Socialnämnd purports to guarantee that legal paternity will be in conformity with the genetic affiliation, since the Socialnämnd will only consent if it is convinced that the acknowledger is the child's parent according to the Swedish grounds for legal parenthood. ${ }^{146}$

Under Dutch and German law the possibilities of annulling marital paternity are much more limited than is the case under Swedish law. A possible explanation for the limitation is that, unlike under Swedish law, Dutch and German law do not have

\footnotetext{
${ }^{141}$ Article 321 French Civil Code.

${ }^{142}$ Article 333 French Civil Code.

${ }^{143}$ Article 335 French Civil Code.

${ }^{144}$ Article 1:2 (2) Children and Parents Code.

${ }^{145}$ Article 1:2 (2) and 1:4 Children and Parents Code.

${ }^{146}$ Article 1:4 and chapter 2 Children and Parents Code.
} 
an institution similar to the Swedish Socialnämnd, which investigates whether the husband is indeed not the child's genetic father. Consequently, the possibility for administrative annulment is limited to only those situations where it is highly unlikely that the husband is the child's genetic father. ${ }^{147}$ Accordingly, under Dutch law, the administrative annulment of marital paternity is only possible if the mother's husband died within 306 days before the birth of the child and if the husband and the wife lived separately from the $306^{\text {th }}$ day before the birth of the child or if they were legally separated, but not divorced (gescheiden van tafel en bed). ${ }^{148}$ If the mother was married at the moment of the child's birth, her new husband will be the child's legal father by dint of the presumption of paternity. ${ }^{149}$ The Dutch provision should be seen in the light of the rule that normally, if the husband died within 306 days before the birth of the child, he will be considered to be the child's father, even if the mother was remarried at the moment of birth. If the marriage has been dissolved by other causes than death, the ex-husband will not be considered to be the child's legal father. ${ }^{150}$

According to German law, the administrative annulment of marital paternity has been introduced in order to avoid expensive judicial procedures in cases where everyone agrees and where it is already at the outset unlikely that the husband is the child's genetic father. ${ }^{151}$ The administrative annulment is only possible if the child was born after the spouses have filed for divorce, but are not yet divorced. In such a case, another man can become the child's legal father by acknowledging paternity within one year after the divorce has become final and if the mother and her (ex)husband consent to the acknowledgment.

\subsection{Evidence and legal parenthood}

The final step in the comparison of the laws on legal affiliation concerns evidence. Evidence is relevant to legal affiliation in two respects. First, a regulation which requires the production of produce tangible evidence of legal reality is the third step which our hypothetical legislator has to take. This step is less interesting in legal systems which use a method of attributing legal parenthood by means of administrative of judicial establishment, because the creation of evidence and the

\footnotetext{
${ }^{147}$ Although this is certainly true for German law, the Dutch reason for an administrative procedure for annulment of legal paternity is less clear. The regulation was inserted in 1998 without any explanation (Second Chamber, 1996-1997, 24 649, nr 28, p. 3 (letter from the State Secretary).

${ }_{148}$ Article 1:199 under b Dutch Civil Code.

149 Ibid.

${ }^{150}$ Article 1:199 under a and b Dutch Civil Code.

${ }^{151}$ BR Drucks. 180/96, p. 63; BT Drucks. 13/4899, p. 53.
} 
establishment of legal parenthood are basically the same thing. However, it becomes more important in a system which allows legal affiliation to arise in e given situation ex lege, such as is the case with legal parenthood under English law and legal maternity under Dutch and German law. In that case, it is interesting to see how the legislator tries to ensure that the evidence actually represents legal reality and to what extent the legislator creates the possibility of correcting that evidence if the legal parenthood thus established does not represent legal reality.

Secondly, evidence is an important issue in court proceedings on legal affiliation. It has been explained above that, in court proceedings concerning establishment or annulment of legal affiliation, it is necessary to prove the existence or absence of a ground for legal affiliation. Especially if genetic affiliation does has to be proven, the question of evidence becomes interesting because the legal systems under consideration give different answers to the question whether a DNA test is to be granted (depending on the circumstances) and to the question what should happen if one or more of the parties do not cooperate with a DNA test.

\subsubsection{Evidence and ex lege existence of parenthood}

When legal parenthood exists ex lege, the issue of registration is important. It has to be examined whether the registration provides for control mechanisms which enhance the chance that the registration is in conformity with legal reality. Under Dutch law, the registration of legal maternity is regulated in the Dutch Civil Code and in the Civil Status Degree 1994 (Besluit Burgerlijke Stand 1994). ${ }^{152}$ Registration of the child's legal mother is mandatory. ${ }^{153}$ According to Article 19e (9) Dutch Civil Code, the civil status registrar is authorised to require a written declaration given by a doctor or midwife that the woman mentioned as the child's mother indeed gave birth to that child. ${ }^{154}$ The registrar is, however, not obliged to ask for such evidence. It happens as a result of fraud or mistake that the birth certificate does not mention the legal mother, but another woman as the child's mother. In that case the birth certificate can be amended on the basis of Article 24 Dutch Civil Code, upon request by an interested party or the public prosecutor. There are neither statutory periods of limitation nor any

\footnotetext{
${ }_{152}$ Stb. 1994/160, last amendment Stb. 2004/190.

153 Article 43 Civil Status Degree 1994. See also J. de Boer, Asser's Personen en Familierecht, Deventer: Kluwer (2002), p. 69.

${ }^{154}$ See also Article 27 Civil Status Degree 1994.
} 
special requirements with regard to evidence. ${ }^{155}$ However, if the child has apparent status in conformity with the affiliation status as recorded in the register, only the child is allowed to apply for an amendment of his or her birth certificate. ${ }^{156}$

Under German law, the registration of civil status is regulated by the Civil Status Act 1937 (Personenstandsgesetz 1937). The procedure for registration of legal maternity under German law is more or less the same as under Dutch law. However, German law does not confer upon the registrar the possibility of requiring a written declaration by a doctor or midwife. In fact, there are no rules regulating how legal maternity should be proven. ${ }^{157}$ If the wrong woman has been registered, for whatever reason, the registration can be changed following proof of the error in court. ${ }^{158}$ The legal basis for such a procedure is either Article 47 Civil Status Act 1937 or Article 640 (2) German Code on Civil Procedure.

Under English law the registration of legal parenthood is regulated by the Births and Deaths Registration Act 1953 and the Registration of Births and Deaths Regulations 1987 (SI 1987/2088). As in the Netherlands and Germany, under English law, the registration of the mother's name and the legal father's name if he is married to the mother is mandatory ${ }^{159}$ and as under German law there is no prescribed form for proving legal maternity. Under English law the registration of the unmarried father (i.e. the father who is not married to the mother of the child) is not mandatory and is regulated by Sections 10 and 10A Births and Deaths Registration Act. ${ }^{160}$ These articles in essence provide that if the child's parents apply to the civil status registrar's office together, or if either the mother or the father is able to produce written evidence of the consent of the other, the father will be registered as father on the birth certificate. ${ }^{161}$ If the registration is disputed, either by one of the persons who has been registered as the child's parent or by someone else who claims to be the legal father, the person can apply for a declaration of parentage under Section 55A Family Law Act 1986. However, and otherwise than is the case a procedure for judicial establishment of parenthood in the above-mentioned continental systems, the court is

\footnotetext{
155 The general rules on evidence apply, Articles 149-207 Dutch Code on Civil Procedure.

${ }^{156}$ Article 1:209 Dutch Civil Code.

${ }^{157}$ Staudinger's Kommentar zum BGB, Part IV/Rauscher, Berlin: Sellier - de Gruyter (2004), p. 188.

${ }^{158}$ Article 60 (2) Civil Status Act 1937.

${ }^{159}$ Section 7 Registration of Births and Deaths Regulations 1987.

${ }^{160}$ The meaning of 'father' has been explained above $\S$ 1.3.1.1. Ex lege existence of parenthood.

${ }^{161}$ Section 10 Births and Deaths Registration Act applies to the registration of the unmarried father at the moment of the registration of the birth. Section 10A applies to the registration of the father after the birth has been registered.
} 
allowed to refuse to hear an application under Section 55A Family Law Act, if the court considers that such application is not in the child's interests. ${ }^{162}$ If the court finds that the registration is incorrect, the birth certificate will be changed accordingly. ${ }^{163}$ The possibility of obtaining a declaration of parentage was introduced by the Child Support, Pensions and Social Security Act 2000 in order to satisfy the need to provide for a determination of legal affiliation which binds everyone. Findings by a court concerning legal affiliation of a child usually only bind the parties, but a decision on the basis of Section 55A Family Law Act 1986 binds everyone. ${ }^{164}$ Pursuant to Section 55A (1) and (3) Family Law Act 1986, any person with a sufficient personal interest has the right to apply to the High Court, a county court or a magistrate's court for a declaration as to whether or not a person named in the application is or was the parent of another person so named. The notion of 'sufficient personal interest' is partly elucidated by Section 55A (4) Family Law Act 1986 and Section 27 of the Child Support Act 1991. On the basis of Section 55A (4) Family Law Act 1986 a child has always sufficient personal interest to apply for a declaration of paternity, just as a man does who wants to establish that he is the father of a child or the mother who wants to establish that a man is the father of her child. In a case in which a maintenance assessment has been made or is in force against a man who denies being the child's father or where the case does not fall within the scope of Section 26 (2) of the Child Support Act 1991, the person with care of the child shall be treated as having a sufficient personal interest for the purposes of Section 55A Family Law Act 1986. Outside the scope of Sections 55A (4) Family Law Act 1986 and Section 27 Child Support Act 1991 the criteria according to which it has to be established whether a person has 'sufficient personal interest' have not yet been decided. In its reaction to the consultation paper on paternity and parental responsibility ${ }^{165}$ the Advisory Board on Family Law ${ }^{166}$ stated in this respect:

\footnotetext{
162 Section 55A (5) Family Law Act 1986.

${ }^{163}$ Section 14A Registration of Births and Deaths Regulations 1987. If a UK court or a foreign court has decided on the affiliation of the child in a procedure other than Section 55A Family Law Act 1986, the birth certificate can be amended on the basis of Section 29A Births and Deaths Registration Act.

${ }^{164}$ Section 58 (2) Family Law Act 1986.

165 Lord Chancellor's Department Consultation Paper, Procedures for the determination of paternity and the law on parental responsibility for unmarried fathers (1998).

${ }^{166}$ The Advisory Board on Family Law is a non-statutory, non-departmental public body which advises the Lord Chancellor.
} 
Others should be able to make an application with leave, if they have a proper interest in the issue. The definition of 'proper interest' was considered in some detail. It would, for example, include siblings who wanted to establish a right to intestate succession, and other family members such as grandchildren. 'Proper interest' not include merely public interest (for example newspapers making applications to establish the paternity of public figures). ${ }^{167}$

\subsubsection{DNA evidence in court proceedings on (legal) affiliation}

The means of proving the absence or existence of genetic affiliation has been the subject of considerable debate and regulation in the legal systems under discussion. Nowadays all countries provide for the possibility of proving genetic affiliation by means of a DNA test; the use of legal presumptions is becoming rare. ${ }^{168}$ However, the conditions under which a court or a private person can obtain a DNA test differ considerably between the legal systems, thus indicating that not all legal systems strive to get to the genetic truth at any price. This paragraph provides the legal framework of the national legal systems under consideration in the context of a request for the use of a DNA test. It will appear that, whereas under English, Dutch and Swedish law the use of DNA tests is not problematic (although not unrestricted either), under French and German law the legislator and the courts have restricted the use of paternity tests more severely than in the aforementioned systems, either to avoid embarrassing situations (e.g. the Yves Montand-affaire in France in 1998) ${ }^{169}$ or to protect the legal family against 'fishing' exercises.

Under English law, the court will order a DNA test unless it is shown that the test is not in the child's interest. The leading cases for the use of a DNA test are $S v . S$ and $W v$. Official Solicitor, in which the House of Lords considered the question whether a blood test should be ordered in a proceeding regarding the paternity and the legitimacy of a child. ${ }^{170}$ The starting-point in the procedure is Section 20 of the Family Law Reform Act 1969, which grants the court the power to order blood tests in cases in which the parentage of a person falls to be determined. First, the court held that the presumption of legitimacy merely determines the onus of proof and that

\footnotetext{
${ }^{167}$ Second Annual Report of the Advisory Board on Family Law (1998/99), Annex C, par. IV.

${ }^{168}$ E.g. For English law: Re F (a minor) [1993] 3 WLR 369, (1993) 143 NLJ 472, [1993] Fam. Law 407; for Sweden: A. Singer, Föräldraskap i rättslig belysning. Uppsala: Iustus Förlag (2000), p. 141.

${ }^{169}$ In 1998 the French actor Yves Montand was exhumed in order to examine whether he was the father of a girl who claimed that she was his daughter. The affaire was one of the reasons to restrict the use of DNA tests after the death of the person whose DNA has to be examined.

${ }^{170}$ [1970] 3 All ER 107, [1970] 3 WLR 366, (1970) 114 SJ 635.
} 
illegitimacy as such is not something from which the child ought in modern circumstances to be protected. Moreover, the general interests of justice require that all the evidence is presented and therefore, a blood test should be directed unless it is shown that the test would be contrary to the child's interest.

The crucial question thus is: when it is in the child's interest not to direct a paternity test? There are hardly any cases in which the court found the direction of a paternity test not in the child's interests. The trend in English case law seems to be to emphasise the need to know the truth about a child's affiliation. ${ }^{171}$ Thorpe LJ stated in this respect that "the paternity of a child is to be established by science and not by legal presumption or inference." ${ }^{172}$ However, in two cases the court refused to order a paternity test: $\operatorname{Re} F$ (a minor) and O. v L. (blood tests). ${ }^{173} \operatorname{In} \operatorname{Re} F$ (a minor) ${ }^{174}$ the applicant argued that he, instead of the mother's husband, was the child's father. The court refused to order a paternity test since, even were it to be established that the applicant was the child's biological father, his chances of obtaining parental responsibility and contact were remote. In O. $v$ L. (blood tests) ${ }^{175}$ the mother requested blood tests to prove that her lover, and not her husband, was the child's father. The child and the husband had had contact for three years when the mother told the husband that he was probably not the father. It appeared that the mother's reason for requesting the blood tests was to exclude contact between the child and the husband. However, such exclusion was not deemed in the child's interests and therefore the request was rejected. If a blood test is ordered and a party refuses to cooperate, the court can draw an adverse inference from the refusal to cooperate with a paternity test. ${ }^{176}$ The person cannot be forced to submit to a blood test. ${ }^{177}$

\footnotetext{
${ }^{171}$ S.M. Cretney e.a., Principles of Family Law, London: Sweet \& Maxwell (2003), p. 528.

${ }^{172} \mathrm{Re} \mathrm{H}$ and A (children) [2002] EWCA Civ 383, [2002] 2 FCR 469, par. 30.

${ }^{173}$ In Re CB (a minor) (blood tests) [1994] 2 FLR 762 the applicant requested blood tests to ascertain whether he or the mother's husband was the child's father. However, the major reason for Wall J. not ordering blood tests seemed to be that he did not consider it relevant to order tests which could not be carried out anyway, since the mother, at that time still had the statutory power obstruct the taking of blood samples from the child. According to Wall J. the court's refusal to order a blood test does not affect the possibility to draw an inference against the mother who refuses to allow a child to be tested.

${ }_{174}^{\text {[1993] Fam } 314 .}$

175 [1995] 2 FLR 930.

${ }^{176}$ Section 23 (1) Family Law Reform Act 1969. Also: Re O; Re J (children)(blood tests: constraints) [2000] Fam 139; F. v Child Support Agency [1999] 2 FCR 385; Re G (parentage: blood sample) [1997] 1 FLR 360; Re H (a minor)(blood tests: parental rights) [1997] Fam 89; Re CB (a minor)(blood tests) [1994] 2 FLR 762.

${ }^{177}$ Section 21 (1) Family Law Reform Act 1969.
} 
Direct references to the child's interests as a criterion for an order for a DNA test are not found in Dutch and Swedish law. ${ }^{178}$ Under Dutch and Swedish law, the emphasis is on the avoidance of unfounded or unnecessary DNA tests. Under Swedish law, the use of DNA tests in cases concerning affiliation is regulated by the Blood Examination Act. ${ }^{179}$ Pursuant to this Act, the court can, on request of one of the parties or on its own motion, order any research to determine a person's genetic characteristics in order to determine the affiliation of the child. ${ }^{180}$ However, in a proceeding for annulment of paternity based on acknowledgment or judicial establishment, the court can only order a paternity test if, after the acknowledgment or the judicial establishment, it turns out that the mother probably had sexual intercourse with another man. ${ }^{181}$ If that is proved, the other man with whom the mother had sexual intercourse must be summoned and subjected to the necessary medical examination. ${ }^{182}$ Moreover, if it was already known before the establishment of paternity that the mother had intercourse with another man, the court cannot order a paternity test. From the parliamentary history it is clear that it is the applicant's knowledge which determines whether the court can order a paternity test. ${ }^{183}$ The reason for limiting the possibility of ordering a paternity test is to avoid unfounded interference by others in the private lives of the father and child. ${ }^{184}$ The limitations on requesting a paternity test do not play a role in case of annulment of marital paternity. It is always possible to request a paternity test in a proceeding for annulment of marital paternity. ${ }^{185}$

If the parties do not co-operate with the court order to undergo medical tests, they can be fined and ultimately they can be forced by the police to undergo the

\footnotetext{
${ }^{178}$ Compare also the absence of the 'child's interest criterion' in actions for judicial establishment under Dutch law and Swedish law with the possibility which an English court has allowed to refuse to hear an application for a determination of parentage on account of the child's interest (see $\S$ 1.4.1. Evidence and ex lege existence of parenthood, note 162).

${ }^{179}$ Lag (1958:642) om blodundersöking m.m. vid utreding av faderskap. See also Förordning (1969:624) om blodundersökning m.m. vid utredning.

${ }^{180}$ Article 1 Lag (1958:642) om blodundersöking m.m. vid utreding av faderskap. See also Å. Saldeen, Karnov, Svensk lagsamling med kommentarer (tenth edition ed.), Stockholm: Thomson Fakta (2005/06), p. 418, note 1; G. Walin, S. Vängby Föräldraskap. En Kommentar. Del I. 1-13 kap (with supplements), Stockholm: Norstedts Juridik (2001), p. 3:34.

${ }^{181}$ Section 1a (1) Blood Examination Act.

${ }^{182}$ Section 1, last sentence Blood Examination Act.

${ }^{183}$ Prop. 1982/83:8, p. 12; Socialstyrelsen, Att fastställa faderskap, Stockholm: Elanders Gotab (2005), p. 66; G. Walin, S. Vängby Föräldraskap. En Kommentar. Del I. 1-13 kap (with supplements), Stockholm: Norstedts Juridik (2001), p. 3:36.

${ }_{184}$ Prop. 1982/83:8, p. 7.

${ }^{185}$ A. Singer, Föräldraskap i rättslig belysning. Uppsala: Iustus Förlag (2000), p. $221 f$.
} 
necessary examinations. ${ }^{186}$ The possibility of invoking enforcement by the police is, in the case of children under the age of 18, limited: samples cannot be taken from a child by means of police assistance if that would be detrimental to the child. ${ }^{187}$

In Dutch law, there are no specific provisions regarding the use of DNA tests. The evidence in a proceeding on affiliation is determined by the general rules of evidence of the Dutch Code on Civil Procedure. ${ }^{188}$ In 2004, the Dutch Supreme Court held that the use of a DNA test in matters concerning legal affiliation is not mandatory. ${ }^{189}$ The limits of that discretion were already determined in 2000, when the Dutch Supreme Court laid down the criteria for the use of a DNA test in matters concerning legal affiliation. ${ }^{190}$ The court held that a DNA test can be ordered if, on the basis of facts and circumstances which have been established during the proceeding, it is plausible that the man is the begetter of the child. Whether it is possible to discharge this burden of proof by means of a privately arranged DNA test has not been decided. If the court orders a DNA test the judge can draw an adverse inference from the refusal to cooperate with the order. ${ }^{191}$ The defence that the DNA test would constitute an infringement of the personal integrity of the person involved is not accepted under Dutch law, since the burden imposed on the individual by the provision of cell materials is negligible compared to the countervailing interests that are at stake. ${ }^{192}$

Under French and German law, the use of DNA tests is regulated more extensively. Under French law, Article 16-11 French Civil Code provides that the genetic identification of persons is only allowed pursuant to a court order. Private tests to determine genetic affiliation are not allowed. In civil proceedings, DNA identification is only allowed for the purpose of determining questions of affiliation and the person involved must consent beforehand to the execution of the tests. Hence, it is not possible to identify a deceased person with a DNA test if that person did not

\footnotetext{
${ }^{186}$ Section 2a (1) Blood Examination Act. See also Prop. 1982/83:8, p. 9, 16.

${ }^{187}$ Section 2a (2) Blood Examination Act.

${ }^{188}$ Articles 149-207 Dutch Code on Civil Procedure.

${ }^{189}$ Dutch Supreme Court, 11 June 2004, NJ 2005/116, RvdW 2004/84.

${ }^{190}$ Dutch Supreme Court, 22 September 2000,NJ 2001/647, m.nt. JdB, RvdW 2000/184.

191 R.J. Blauwhoff, 'Procesrechtelijke kunstgrepen bij de gerechtelijke vaststelling van het vaderschap' Tijdschrift voor Familie- en Jeugdrecht (2006), p. 132-138, at p. 133; A. Heida, 'Vaderschapsprocedures en DNA-onderzoek. Tijdschrift voor Familie- en Jeugdrecht (2002), p. 122129 , at p. 127.

${ }^{192}$ Advocate General Wesseling - van Gent in HR 9 December 2005, LJN AU3262, Advocate General Bakels in HR 22 September 2000, NJ 2001/647, J. de Boer, Asser's Personen en Familierecht, Deventer: Kluwer (2002), nr. 738.
} 
expressly consent to such test during his or her lifetime. In such case it is necessary to resort to other means of proving that the deceased person is the father of the applicant. ${ }^{193}$ Furthermore, in French law a DNA test in a proceeding on legal affiliation is de droit (as of right), ${ }^{194}$ meaning that, within the framework of Article 16-11 French Civil Code, the court is obliged to order medical examination on the request of either party, unless there are legitimate reasons not to do so. ${ }^{195}$ The court order is essential, since without the order it is not possible at all to execute a DNA test. ${ }^{196}$ Legitimate reasons for rejecting a request for a DNA test are: that the request is only being made in order to delay the establishment of legal paternity, ${ }^{197}$ that the test is requested in order to establish legal affiliation whereas the law prohibits such establishment, ${ }^{198}$ or in case of fishing exercises or other abusive intentions. ${ }^{199}$ Notwithstanding that to an order for a DNA test is a matter of right, the Cour de Cassation held in 2003 that the refusal to cooperate with the court order for a paternity test is not enough to establish a presumption of paternity against that person. $^{200}$ The party who requested the test has to submit further evidence which supports the paternity of the alleged father. ${ }^{201}$

Under German law, the applicant has to present an Anfangsverdacht (ground for reasonable suspicion) before an application on legal affiliation will be heard at all. ${ }^{202}$ According to the Bundesgerichtshof the applicant must

\footnotetext{
${ }^{193}$ For examples see; A. Pascal, M. Trapero, 'Vérité biologique et filiation dans la jurisprudence récente de la Cour de Cassation', in La vérité. Rapport annuel 2004 de la Cour de Cassation, Paris: La documentation Française (2005).

${ }^{194}$ Cass. 1er civ., 28 May 2000, 30 May 2000, Dalloz 2001, p. 1427; Cass. 1er civ., 17 September 2003 (01-03.408), Dalloz 2004, p. 659; S. LeGac-Pech, 'De Louis XVII à Z ...' Recueil Dalloz (2001), 404407.

${ }^{195}$ The parties in a proceeding concerning legal affiliation only have the right to a DNA test if the child's genetic affiliation is relevant to the resolution of the dispute. If the applicant has to challenge the child's apparent status the genetic affiliation is irrelevant and neither party has a right to a DNA test (Cass. 1er civ., 6 December 2005, D. 2006, p. 99; F. Granet-Lambrechts, J. Hauser, 'Le nouveau droit de la filiation', Recueil Dalloz (2006), p. 17-28, at p. 23; F. Granet-Lambrechts, 'Droit de filiation: panorama 2004', Recueil Dalloz (2005),p. 1748-1754, at p. 1751).

${ }^{196}$ Article. 16-11 (1) French Civil Code.

${ }^{197}$ Cass. 1er civ., 14 June 2005 (03-19.325), Dalloz 2005, p. 1804.

${ }^{198}$ F. Ferrand, 'Verwertung heimlich eingeholter DNA-Vaterschaftstests', Zeitschrift für Europäisches Privatrecht (2006), p. 436-458, at p. 454.

${ }^{199}$ F. Granet-Lambrechts, 'Droit de la filiation', Recueil Dalloz (2006), p. 1139-1148, at p. 1143.

${ }^{200}$ Cass. 1er civ., 17 September 2003 (01-13.856), Dalloz 2004, p. 659. See also: Jacques Massip, Dalloz 2005, p. 660 ; Frédérique Granet-Lambrechts, Dalloz 2004, p. 1420.

${ }^{201}$ See also F. Granet-Lambrechts, 'Droit de la filiation', Recueil Dalloz (2006), p. 1139-1148, at p. 1143; A. Pascal, M. Trapero, 'Vérité biologique et filiation dans la jurisprudence récente de la Cour de Cassation', in La vérité. Rapport annuel 2004 de la Cour de Cassation, Paris: La documentation Française (2005).

${ }_{202}$ BGH 22 April 1998 (nr. XII ZR 229/96), FamRZ 1998, p. 955; BGH 30 October 2002 (nr. XII ZR 345/00), FamRZ 2003, p. 155. See also F. Ferrand, 'Verwertung heimlich eingeholter DNA-
} 
Umstände vortragen, die bei objectiever Betrachtung geeignet sind, Zweifel an der Abstammung des Kindes von dem als Vater geltenden Kläger zu wecken und die Möglichkeit der Abstammung des Kindes von einem anderen Mann als nicht ganz fernliegend erscheinen zu lassen. ${ }^{203}$ (present circumstances which, when viewed objectively, raise doubt whether the applicant who is presumed to be the child's legal father actually is the father and the possibility that another man is the child's father is not entirely remote (tr. authors)

The reason for the requirement of an Anfangsverdacht is to avoid paternity suits 'out of the blue'. One way to make an Anfangsverdacht is by establishing that it is probable that the mother has had sexual intercourse with another man. This is not readily established. In the case which came before the Bundesgerichtshof just mentioned, the fact that the child's mother had stated at various occasions that she loved the alleged father was not enough. ${ }^{204}$ Also the fact that the mother refused to submit to a paternity test ${ }^{205}$ or limited fertility of the legal father ${ }^{206}$ is, as such, not enough to make an Anfangsverdacht. Another way of presenting an Anfangsverdacht is by means of a privately-ordered paternity test. ${ }^{207}$ However, in case of a paternity test it is important that all the parties involved consent to the test. In two decisions in 2005, the Bundesgerichtshof held that the use of paternity tests without the consent of the persons involved in order to make an Anfangsverdacht, is not permitted. ${ }^{208}$ The court gave various reasons for its decision. First of all, in the absence of consent there

\footnotetext{
Vaterschaftstests', Zeitschrift für Europäisches Privatrecht 2006, p. 436-458, at p. 445ff; C. Rittner, N. Rittner, 'Rechtsdogma und Rechtswirklichkeit am Beispiel so genannter heimlicher Vaterschaftstests' Neue Juristische Wochenschrift (2005), 945-948, p. 945; M. Wellenhofer, 'Die prozessuale Verwertbarkeit privater Abstammungsgutachten' Zeitschrift für das gesamte Familienrecht (2005), p. 665-668, p. 665; A. Wolf, 'Biologische Abstammung und rechtliche Zuordnung', Neue Juristische Wochenschrift (2005), p. 2417-2421, p. 2419; Staudinger's Kommentar zum BGB, Part IV/Rauscher, Berlin: Sellier - de Gruyter (2004), p. 318.

${ }^{203}$ BGH 12 January 2005 (nr. XII ZR227/03), FamRZ 2005, 342. Also F. Ferrand, 'Verwertung heimlich eingeholter DNA-Vaterschaftstests', Zeitschrift für Europäisches Privatrecht 2006, p. 436458 , at p. 446.

${ }^{204}$ BGH 30 October 2002 (nr. XII ZR 345/00), FamRZ 2003, p. 155.

${ }^{205}$ BGH 12 January 2005 (nr. XII ZR60/03), NJW 2005, 497; FamRZ 2005, 665.

${ }^{206}$ BGH 12 January 2005 (nr. XII ZR227/03), FamRZ 2005, 342.

${ }^{207}$ Staudinger's Kommentar zum BGB, Part IV/Rauscher, Berlin: Sellier - de Gruyter (2004), p. 321, nr. 21.

${ }^{208}$ BGH 12 January 2005 (nr. XII ZR60/03), NJW 2005, 497; FamRZ 2005, 665 and BGH 12 January 2005 (nr. XII ZR227/03), FamRZ 2005, 342. On these decisions see i.a. F. Ferrand, 'Verwertung heimlich eingeholter DNA-Vaterschaftstests', Zeitschrift für Europäisches Privatrecht 2006, p. 436458; M. Wellenhofer, 'Die prozessuale Verwertbarkeit privater Abstammungsgutachten' Zeitschrift für das gesamte Familienrecht (2005), p. 665-668, p. 666.
} 
can be no absolute certainty that the material used for the DNA-test is actually from the party involved. Moreover, removal of the material without consent of the party involved violates that person's right to personal integrity as enshrined in Article 2 (1) of the German Constitution.

If the applicant has raised an Anfangsverdacht the court will examine the application for annulment of paternity. In examining the application the court is obliged to collect all the evidence which is necessary for the determination of the question. The court can order a medical test ex officio or at the request of the parties. $^{209}$ The persons involved are obliged to cooperate with the medical test if the testing method is effective and if the medical examination is harmless to the person's health. ${ }^{210}$ A refusal to cooperate without a good reason or without any reason at all can ultimately be sanctioned with imprisonment for the duration of the proceedings ${ }^{211}$ and the unwilling person can be physically forced to undergo medical tests for the purpose of judicial establishment of paternity. ${ }^{212}$

\section{The European Court of Human Rights and national laws of parenthood}

In the first part we have reviewed the breadth of scope of the law of parenthood in its totality and have observed considerable differences between the national laws on legal parenthood in England \& Wales, France, Germany, the Netherlands and Sweden. In this part the case law of the European Court in the field of legal parenthood will be examined. The main question is what, according to the case law of the European Court, are the constitutive elements of family or private life and what is the degree of respect which the states are required to observe in relation to that particular dimension of family or private life, under Article 8 ECHR on the basis of which the national legal systems are obliged to allow for the establishment of legal parenthood. To the extent to which the European Court insists upon compliance by the Member States with a minimum assortment of rules, it is will be possible to speak of a trend by which Member States are obliged to bring their rules closer together. We will now examine whether such is the case, and, if so, to what extent.

\footnotetext{
${ }^{209}$ Article 640 in conjunction with 616 ZPO.

${ }^{210}$ Article 372a (1) ZPO. See also: R. Frank, 'Die zwangsweise körperliche Untersuchung zur Feststellung der Abstammung’ Zeitschrift für das gesamte Familienrecht (1995), p. 975-981.

${ }^{211}$ Article 390 (1) ZPO.

${ }^{212}$ Article 372a (2) ZPO, see also Staudinger's Kommentar zum BGB, Part IV/Rauscher, Berlin: Sellier - de Gruyter (2004), p. 114, 118; Münchener Kommentar zum BGB Volume 8/Seidel (2002), p. 230; A. Lüderitz, Familienrecht, Beck'she Verlagsbuchhandlung: München (1999), p. 270.
} 


\subsection{Parenthood: natural reproduction and assisted reproduction}

In the foregoing sections we have seen that a distinction is made in the national legal systems regarding the establishment of natural parenthood and the establishment of parenthood in consequence of assisted reproduction. We have shown that, in most legal systems, the ground for legal paternity is genetic affiliation in case of natural reproduction and intention in case of assisted reproduction. Even in legal systems such as Germany and the Netherlands where it has been submitted that intention is not the ground for legal affiliation, the requirement of consent to assisted reproduction has the effect that different rules apply than in the case of natural reproduction.

In the international setting this distinction can also be made. The distinction is found in the documents prepared under the auspices of the Council of Europe. For example, parenthood in consequence of natural reproduction is covered by the European Convention on the Legal Status of Children Born Outside Wedlock. ${ }^{213}$ The Committee of Experts on Family Law of the Council of Europe is still working on a new convention which will try to improve the Luxembourg Convention. Pursuant to this project the White Paper on Principles Concerning the Establishment and Legal Consequences of Parenthood was published in 2002. ${ }^{214}$ However, the distinction between natural parenthood and assisted reproduction is not a matter of principle and is therefore not water-tight. In the White Paper the first seventeen principles, which deal with the establishment of parenthood, include principles relating to 'lowtechnology' assisted reproduction techniques such as surrogacy and sperm donors.

Parentage in consequence of assisted reproduction is addressed by the work of the Ad Hoc Committee of Experts on the Developments in Bio-Medical Sciences (CAHBI), which in 1989 presented 21 principles to the Committee of Ministers. Those principles were not accepted. Since 1992 the work of CAHBI on assisted reproduction continues as part of the work of the steering committee on bio-ethics. That committee produced the Oviedo Convention for the Protection of Human Rights and Dignity of the Human Being with Regard to the Application of Biology and Medicine. ${ }^{215}$ The First Protocol to that convention, containing a prohibition on cloning of human beings, came into force in $2001 .^{216} \mathrm{~A}$ further protocol dealing with

\footnotetext{
${ }^{213}$ Opened for signature at Luxembourg, European Treaty Series nr. 85, in force $11^{\text {th }}$ August 1978.

${ }^{214}$ Published at Strasbourg, 15th January 2002, CJ-FA (1001) 16 rev.

${ }^{215}$ Signed on 4th April 1997, and in force $1^{\text {st }}$ December 1999.

216 Additional Protocol to the Convention for the Protection of Human Rights and Dignity of the Human Being with regard to the Application of Biology and Medicine, on the prohibition of the
} 
the ethical aspects of the human genome and the development of new technology such as DNA chips is currently being prepared. This new protocol will deal, in a first part, with issues of individual genetic tests, screening programmes, gene therapy and genetics research. Issues of consent and quality of genetic services will be addressed, as well as, in a second part, the use of genetic tests in connection with employment and insurance. ${ }^{217}$ The point here is that in the international context, a distinction is made between the different activities of the Council of Europe regarding, on the one hand, the principles applicable to natural reproduction and, on the other hand, the principles in the context of assisted reproduction. The same distinction can be found in the case law of the European Court, regarding establishment of parenthood. Accordingly the situations are distinguished in the discussion which follows.

\subsection{Natural reproduction and legal parenthood}

In this section a distinction is made between the establishment of the mother-child relationship and the child-father relationship.

\subsubsection{The child-mother relationship}

In Marckx $v$ Belgium the European Court held that the absence in Belgian law of the possibility for the unmarried mother Paula Marckx to establish, without serious disadvantages in matters such as inheritance law, a legal affiliation link between herself and her daughter Alexandra Marckx, violated Article 8 ECHR (lack of respect for private and family life), Article 14 in conjunction with the First Protocol, Article 1 ECHR (discrimination regarding quiet enjoyment of possessions) and Article 14 in conjunction with Article 8 ECHR (discrimination regarding respect for family life). The state's obligation imposed by Article 8 ECHR to respect family life

'means, amongst other things, that when the State determines in its domestic
legal system the régime applicable to certain family ties such as those between
an unmarried mother and her child, it must act in a manner calculated to allow
those concerned to lead a normal family life. As envisaged by Article 8 ,
respect for family life implies in particular, in the European Court's view, the

Cloning of Human Beings, European Treaty Series nr. 168, signed on $12^{\text {th }}$ January 1998 ; in force $1^{\text {st }}$ March 2001.

${ }_{217}$ The first meeting on the new protocol was in September 1997. The steering committee on BioEthics considered the first part of the protocol in March $2004\left(26^{\text {th }}\right.$ meeting of the steering Committee $16^{\text {th }}-19^{\text {th }}$ March 2004). The second part is currently under consideration. 
existence in domestic law of legal safeguards that render possible as from the moment of birth the child's integration in his family. In this connection, the State has a choice of various means, but a law that fails to satisfy this requirement violates paragraph 1 without there being any call to examine it under paragraph 2.'218

In considering the rules of the national syatems above, it has been seen that only French law takes account of social factors which can influence whether a woman is or is not the child's mother (part. 1.2.1.2); in all other systems the decisive fact is that of giving birth to the child (part. 1.2.1). It will be seen below that, in relation to the father-child relationship, the European Court attaches considerable importance to the presence of social elements in the relationship between the parents or failing that between the child and the person regarding whom the legal affiliation link to the child is at issue. Regarding the European Court's judgment in the Marckx case, it is not entirely clear whether the European Court intended that the state's duty to provide for the establishment of the mother-child relationship arises purely by dint of birth or whether social elements were also considered relevant. In the Marckx case this matter was not put at issue since Paula and Alexandra did have a close social, as well as a biological, link to one another. The European Court remarks:

'Besides, it is not disputed that Paula Marckx assumed responsibility for her daughter Alexandra from the moment of her birth and has continuously cared for her, with the result that a real family life existed and still exists between them. 219

It is not certain that the European Court intended with this statement to imply that social facts regarding the mother-child relationship were needed to be established before the principles stated above requiring the establishment of parenthood could be activated. The fact that the requirement applies unconditionally and from the moment of birth suggests the contrary. In Principle 1 of the White Paper on Parenthood it is stressed that the bare fact of the birth determines legal maternal affiliation. Social aspects, such as the quality of the mother-child relationship are not relevant to the

\footnotetext{
${ }^{218}$ Eur. Ct. H. R. 13th June 1979, Series A vol. 31, § 31.

${ }^{219}$ Eur. Ct. H. R. 13th June 1979, Series A no. 31, § 31.
} 
determination of the legal affiliation link. The Explanatory Notes to the White Paper state 'all previous circumstances concerning the conception and pregnancy (e.g. cases of surrogacy) and any subsequent modification of the legal parentage (e.g adoption by another person) will not affect the legal maternal affiliation at the moment of birth. ${ }^{220}$ By contrast, when the establishment of the father-child relationship is at issue, it will be seen below that the social character of the relationship between the mother and the man claiming to be the father or the relationship between the man and the child are of great importance.

\subsubsection{The child-father relationship}

It has been seen above, in the consideration of the national systems, that the national systems allow for certain social circumstances, public and private interests which have an impact upon the possibility of establishing or annulling legal parenthood by a man (part. 1.3 above). One example are the restrictions applying to sperm donors on establishing parenthood at all (part 1.3.1.3 (a)), the rules on locus standi regarding the establishment of parenthood (part. 1.3.1.3 (b)), the restrictions on judicial annulment of paternity, (part. 1.3.1.4(b)) and the impact of apparent status and locus standi on the possibility of obtaining judicial annulment (part. 1.3.1.4(c) and (d)), and the use of statutory periods to restrict annulment of paternity (part. 1.3.1.3(e)). In various ways these rules take account of social elements in the relationship between the mother, legal father, putative father and the child. It will be seen below that, in relation to the father-child relationship, the European Court attaches importance to the presence of social elements in the relationship between the parents or failing that between the child and the person regarding whom the legal affiliation link to the child is at issue. However it will be seen that the European Court's main instrument is an instrument which does not appear within the scheme of our review of national laws at all: the presence or absence of a conflict of interest between the parties.

In the case law of the European Court regarding the establishment of the relationship between the child and the man claiming to be father there are three features which the European Court finds important:

\subsubsection{The presence or absence of a biological link between the man and the child.}

In many of the cases there was no dispute regarding the biological link between the man and the child. However, presence of a biological link was disputed in the

\footnotetext{
${ }^{220}$ Published at Strasbourg, 15th January 2002, CJ-FA (1001) 16 rev., page. 5.
} 
admissibility decision of the European Court in Nylund $v$ Denmark. ${ }^{221}$ The male applicant had had a brief relationship - lasting nine months, with cohabitation lasting seven months - with a woman. In the last two months of that period of cohabitation the woman became pregnant. Before the child was born the woman broke off the relationship with the applicant and married another man. The applicant, who had no right under Danish law to challenge the legal presumption of paternity arising by dint of marriage in favour of the mother's husband, brought his complaint to the European Court, alleging that Article 8 ECHR should give him the right to prove with DNAtesting that he was the child's father. The European Court stated:

'The Court notes that the instant case differs from the Rasmussen $v$ Denmark $^{222}$ case in two respects. Firstly, in the Rasmussen case a husband wished to institute proceedings contesting his own paternity. Secondly, in that case the action aimed at the determination of the legal relations between the man and the child. In the instant case, the applicant's action is aimed at the confirmation of an alleged biological fact rather than at the establishment of legal relations. The Court finds, nonetheless, that the circumstances in the applicant's life in the spring of 1988, as described by the applicant himself, were such as to bring the facts of the instant case within the ambit of Article 8.'

The fact that the biological link was contested was not fatal to the claim but caused the European Court to analyse the case as 'private life' rather than 'family life. For another reason discussed below in section 2.2.2.3 the European Court went on to hold the application inadmissible.

\subsubsection{The social relationship between the mother and father or between the father and} the child

The first step which the European Court takes when examining a complaint under Article $8 \mathrm{ECHR}$ is to examine whether there is a relationship which can be qualified as 'private or family life' between the man alleging to be the father of the child and the mother. Family life can be established in one of two ways: if the relationship between the mother and the man alleging to be the father is of sufficient quality to

\footnotetext{
${ }^{221}$ Application nr. 27110/95, 29th June 1999.

${ }^{222}$ Rasmussen v Denmark, Eur. Ct. H.R., 28th November 1984.
} 
qualify as 'family life', then the child who is born out of that relationship will be taken to have a relationship of 'family life' with the man concerned. Thus if the mother and father are married or have been, even though they have divorced by the time the child is born, there will be family life within the meaning of Article 8 ECHR. $^{223}$ If the mother and father have lived together in a stable relationship for a long time (in the case in question nineteen years) there will be family life, even if the mother was throughout married to someone else. ${ }^{224}$ However even quite a short period of cohabitation, eleven months for example, may be enough to establish family life, if, for instance, the couple furthermore has marriage plans and the pregnancy was planned. ${ }^{225}$ If the mother and father do not live together, but have a relationship of 'sufficient constancy' (in the case in question, they had four children together), there will also be family life. ${ }^{226}$ In all these cases the European Court focuses upon the quality of the relationship between the parents and if on that basis 'family life' within the meaning of Article $8 \mathrm{ECHR}$ is found to be present, the child is held to be included within that family life. Thus the European Court said in Keegan v Ireland:

'A child born out of such a relationship is ipso iure part of the "family" unit from the moment of his birth and by the very fact of it. ${ }^{, 227}$

If the man is not able to show sufficient quality in the relationship between himself and the mother he may nevertheless demonstrate that there is a relationship of 'family life' between himself and the child. In these cases the European Court focuses upon the quality of the actual contacts between the child and the man. However the European Court recognises that the mother has great power in this situation to thwart the development of social contacts between the child and the father. Thus the European Court has qualified even rather limited contacts between the child and the father, provided the father has shown consistent 'commitment' to the development of a relationship between himself and the child. Thus in Lebbink $v$ The Netherlands the mother and father had lived together for about three years, but ceased cohabiting when the child was born. Perhaps this period of three years' cohabitation was already

\footnotetext{
${ }^{223}$ Berrehab v The Netherlands, Eur. Ct. H.R. $21^{\text {st }}$ June 1988, Series A no. 138, $§ 21$.

${ }^{224}$ Johnston v Ireland, Eur. Ct H.R. 18th Deecember 1986, Series A no. 112.

${ }^{225}$ Keegan v Ireland, Eur. Ct H.R. 26th May 1994, Series A no. 291, §§ 44-45.

${ }^{226}$ Kroon v The Netherlands, Eur. Ct. H.R. 27 October 1994, Series A no. 297-C § 30.

${ }^{227}$ Keegan v Ireland, Eur. Ct. H.R. 26th May 1994, Series A no. 291, § 44.
} 
enough to qualify the relationship between the mother and father as family life, on the same basis as in Keegan. However the European Court went on to note that the father, although he had never lived with the child, was present at the birth, and had visited her on several occasions and shown interest in the child's problems with her hearing. The totality of these factors supported a conclusion that there was family life between him and his daughter. ${ }^{228}$ In conclusion: when the establishment of parenthood between the father and child is at issue, social factors are an important element in the European Court's case law. As suggested above, the situation when establishment of the father-child relationship is at issue probably contrasts with the situation when the mother-child relationship is at issue.

\subsubsection{Presence or absence of a conflict of interest regarding the establishment of parenthood.}

Where there is no collision in the interests of the mother, father or child regarding the establishment of the father-child relationship, the European Court takes the view that national law should make provision for such legal establishment. Thus the European Court stated in Kroon $v$ The Netherlands:

'According to the principles set out by the Court in its case-law, where the existence of a family tie with a child has been established, the State must act in a manner calculated to enable that tie to be developed and legal safeguards must be established that render possible as from the moment of birth or as soon as practicable thereafter the child's integration in his family (see, mutatis mutandis, the above-mentioned Keegan judgment, p. 19, para. 50). ${ }^{229}$

This principle is close to the principle quoted in section 2.2.1 above in the Marckx case in relation to the establishment of the mother-child relationship. The European Court, when regaled by arguments brought by the Dutch government as to why the father-child relationship should not be allowed to be recognised, responded:

'In the Court's opinion, "respect" for "family life" requires that biological and social reality prevail over a legal presumption which, as in the present case, flies in the face of both established fact and the wishes of those concerned

\footnotetext{
${ }^{228}$ Lebbink $v$ The Netherlands, Eur. Ct. H.R., 1st June 2004.

${ }^{229}$ Kroon v The Netherlands, Eur. Ct H.R. 27th October 1994, Series A no. 297-C $§ 32$.
} 
without actually benefiting anyone. Accordingly, the Court concludes that, even having regard to the margin of appreciation left to the State, the Netherlands has failed to secure to the applicants the "respect" for their family life to which they are entitled under the Convention. ${ }^{, 230}$ (emphasis added)

This approach, we suggest, is a key feature in the European Court's case law regarding parenthood. In the italicised phrase - referred to below as the 'biological and social reality rule,' the European Court is remarking inter alia that there is no conflict of interest between the mother, father and child regarding the establishment of the relationship between the father and child.

This principle was applied in Nylund $v$ Denmark ${ }^{231}$, discussed in section 2.2.2.1 above. Declaring the applicant's claim inadmissible, the European Court noted that the reason that the Danish Court of Appeal had rejected the applicant's claim was because allowing the DNA-testing would not have been in the child's interests. It also referred to the disturbance such an examination would cause to the family relationships in the child's family.

The question whether the establishment of the father-child relationship presents a collision between the interests of the mother, father and child is of greater weight in the European Court's case law than the question whether there are biological ties (issue (1) above) or social ties between the father and child (issue (2) above). This principle is shown by the case of Yousef $v$ The Netherlands. ${ }^{232}$ In Yousef there was no doubt whatsoever that the father was the child's biological father and furthermore the Dutch courts had allowed him to enjoy a right of access to his daughter. However the mother had always been opposed to the father being allowed to recognise the child. Under Dutch law her consent to recognition by the father was required; however the father was entitled to apply to the court for substitution of this consent. The father had made such application but the court had refused to substitute the mother's consent. Even after the mother died (when the child was seven) and the father applied once again for permission to recognise the child and thus to establish a legal affiliation link to her, the courts at all instances refused the permission. The father applied to the European Court alleging violation of Article 8 ECHR. When one

\footnotetext{
${ }^{230}$ Kroon v The Netherlands, Eur. Ct. H.R. $27^{\text {th }}$ October 1994, Series A no. 297-C $\S 40$.

${ }^{231}$ Application nr. 27110/95, 29th June 1999.

${ }^{232}$ Yousef $v$ the Netherlands, Eur. Ct. H.R. $5^{\text {th }}$ December 2002, RJD 2002-VIII, p. 245.
} 
considers the strength of the principle originated by the European Court in Marckx $v$ Belgium and then applied in the cases of Johnston $v$ Ireland, Keegan $v$ Ireland and Kroon $v$ The Netherlands as explained above (and quoted in the first quotation (from the Kroon case) in this section, it is clear that the father's claim to recognise the child was covered by the general rule. The European Court nevertheless upheld the decision of the Dutch courts, who judged that the child's interests would not be served by allowing the father to recognise her. ${ }^{233}$ This case provides a very clear indication of the decisive effect in the European Court's case law of the presence of a conflict of interest (in the case in hand, between the father and the child) - coupled with the primacy of the child's interests - regarding the establishing of the father-child relationship.

\subsubsection{Legal recognition of family life: the criteria}

From the study of the European Court's leading case law on the establishment of the father-child relationship we have derived in the previous section three elements which play a role in the decisions: (1) a biological link; (2) the social factors, whether derived from the relationship between the father and the mother or between the father and the child or possibly a combination of both; (3) the presence or absence of a conflict of interest. These features apply in a given case in combination. We will now examine with a brief overview what the combined effect is of these features. The examination of the elements in combination will indicate the relative weight accorded by the European Court to the three elements.

In Marckx v Belgium, there was an undisputed biological link, and furthermore social links, although, as signalled above in part 2.2.1, in the case of the mother-child relationship a social link is probably not required. Furthermore, there was no conflict of interest regarding the establishment of the mother-child relationship. The European Court held that Articles 8, 14 and First Protocol, Article 1 ECHR were violated, and Belgium was required to adjust its laws in order to make possible the establishment of the mother-child relationship.

In Keegan $v$ Ireland, there was a biological link between the child and the father, moreover there were sufficient social factors, qualifying as 'family life', to attract the protection of Article 8 ECHR. In this case there was no conflict between the interests of the mother, father and child regarding the establishment of parenthood.

${ }^{233}$ Yousefv the Netherlands, Eur. Ct. H.R. $5^{\text {th }}$ December 2002, RJD 2002-VIII, p. 245, § 51. 
In that case what was at issue was the father's right to be informed that the mother had placed the child for adoption so that he was in a position to take steps to establish a legal affiliation link or other steps in relation to her. In this case there was no conflict of interest in fact as the child had long since been placed for adoption so that the father had no hope of exercising his rights. But on the hypothesis that he had been on time with his claim, there still would not necessarily have been a conflict of interest. The mother, by placing the child for adoption, had no interest in stopping the father from establishing a link to the child, at least in the absence of an indication that the establishment of the child-father relationship was against the child's interests. In Keegan's case the European Court found a violation of Article 8 ECHR by the fact that Irish law gave the father no right to be informed of the adoption and therefore no right to protect any rights regarding the legal affiliation link between himself and the child. In Kroon $v$ The Netherlands the analysis is similar: there was a biological link between the father and child, there were social links and there was no conflict of interest between the mother and the father of child regarding the establishment of a legal affiliation link. The European Court held that the Netherlands had to change its law to make it possible to establish the legal affiliation link.

The break in the line is Yousef $v$ The Netherlands, in which case there was a biological and social link between the child and the father. But in this case there was a conflict of interest: the courts were convinced that the establishment of the legal affiliation link between the child and father was not in the child's interests. In Yousef's case the European Court found no violation of Article 8 ECHR and there was no responsibility on the state to allow the legal affiliation link between the child and father to be created. This case confirms the overall picture that the presence or absence of a conflict of interest between the mother, father and child regarding the establishment of the legal affiliation link between the child and father plays a decisive role in the European Court's decision to intervene regarding the national rules on the establishment of parenthood.

\subsubsection{Private life and legal parenthood}

In a number of cases the European Court has examined issues relating to parenthood in relation to the duty of the state under Article 8 ECHR to respect the 'private life' of the applicants. It is necessary to examine these cases to obtain a more complete picture of the vision which the European Court has developed regarding the minimum 
standards with which the member states are required to comply regarding the laws of parenthood or laws closely related therewith. These 'private life' cases will be examined in the light of the three elements given above.

In Odièvre v France ${ }^{234}$ the European Court was confronted with the question whether the system of accouchement sous $X$ allowed by the French Civil Code is compatible with the right, guaranteed by Article 8 ECHR, to private life of the person who is born as a result of anonymous birth. (This system is referred to in part 1.3.1.2 above, by footnote 68). The European Court had to balance, on the one hand, the interests which the system of accouchement sous $X$ aims to protect, namely, the rights to privacy of the mother who has become pregnant in unhappy circumstances and the interests of the state in preventing resort by such desperate women to illegal abortion or child abandonment, and, on the other hand, the right or interest of the person thus born to know the identity of the mother and preferably also the father. The European Court held that France was entitled to preserve the secrecy of the mother's identity. The European Court contrasted the issue in Odièvre with the situation in Mikulić v Croatia, ${ }^{235}$ where the issue raised was the slowness and ineffectiveness of the procedures to establish whether a certain man was the child's biological father. Regarding the conflict of interest the European Court in Odièvre said:

'On the one hand, people have a right to know their origins, that right being derived from a wide interpretation of the scope of the notion of private life. .... On the other hand, a woman's interest in remaining anonymous in order to protect her health by giving birth in appropriate medical conditions cannot be denied. In the present case, the applicant's mother never went to see the baby at the clinic and appears to have greeted their separation with total indifference (see paragraph 12 above). Nor is it alleged that she subsequently expressed the least desire to meet her daughter. The Court's task is not to judge that conduct, but merely to take note of it. The two private interests with which the Court is confronted in the present case are not easily reconciled; moreover, they do not concern an adult and a child, but two adults, each endowed with her own free will. ${ }^{, 236}$ (emphasis added)

\footnotetext{
${ }^{234}$ Odièvre v France, Eur. Ct. H.R. $13^{\text {th }}$ February 2003.

${ }^{235}$ Mikulić v Croatia, Eur. Ct. H.R., $7^{\text {th }}$ February 2002, RJD 2002-I.

${ }^{236}$ Odièvre v France, Eur. Ct. H.R. $13^{\text {th }}$ February 2003, $\$ 44$.
} 
Applying the analysis as developed above, in Odièvre's case there was a biological link, but no social links between the child and the mother. For that reason the case was classified as 'private life' rather than 'family life'. There was a conflict of interest between the right to privacy of the mother and the child's right to know the identity of the person from whom she was biologically descended. That conflict of interest played a central role in the European Court's conclusion that Article 8 ECHR had not been violated by the rule protecting anonymous birth.

In Znamenskaya $v$ Russia the European Court considered an application by Natalya Vasilyevna who had given birth to a stillborn child on $1^{\text {st }}$ August 1997 after a pregnancy of thirty-five weeks. Her complaint concerned the refusal of the Russian authorities to allow her to record her deceased partner as the child's biological father, including the consequential change of the stillborn child's name to include the patronymic name. The partner had been put in a detention facility on $20^{\text {th }}$ June 1997 , some six weeks before the child was stillborn, when the pregnancy was about twentynine weeks advanced. The partner died in custody on $12^{\text {th }}$ October 1997 . Because of this detention, said the applicant, the partner had not been able to file a joint application with her to officially record the partner as the child's father. In her application based on Article 8 ECHR the applicant relied specifically ${ }^{237}$ upon the principle 'biological and social reality principle' established in Kroon $v$ The Netherlands, (and identified in part 2.2.2.3 above (second quotation in that part)) as establishing the relevance of an absence of conflict of interest when furthering a claim based on Article 8 ECHR. In Znamenskaya there was no dispute regarding the biological link, but the paternity established by law was alleged to conflict with the social facts. ${ }^{238}$ In such case the role of social fctors is considerable.

The analysis of the social links in this case is rather strange. The European Court did not find sufficient social links to justify a finding of family life, but on the basis of the link between the mother and the unborn child found private life to be established. The European Court ignored the relationship between the mother and alleged father of the unborn child. ${ }^{239}$ As shown in the quotation from Kroon $v$ The Netherlands cited in part 2.2.2.3 above, the European Court's previous case law

\footnotetext{
${ }^{237}$ Znamenskaya v Russia, Eur. Ct. H.R. $12^{\text {th }}$ October 2005, § 21.

${ }^{238}$ Although in the absence of DNA-testing the assumption that there was a biological link between the father and child is risky as the father was dead and therefore not able to defend his interests.

${ }^{239}$ Znamenskaya v Russia, Eur. Ct. H.R. $12^{\text {th }}$ October 2005, § 27.
} 
establishes that the relationship between the mother and father, if qualifying as 'family life', can be sufficient to establish 'family life' between the father and child. This would apply even though the father died before the birth, and thus, just like the father in Keegan, was unable to establish any social links to the child. The European Court seems to have overlooked this possibility, and in particular the mother's assertion - and its implications for the establishment of family life - that she had lived with the alleged father since 1994, meaning a cohabitation of between two and three years. ${ }^{240}$ The fact that the mother was throughout the relevant period married to another man does not affect the relevance of facts tending to establish family life; in Kroon $v$ The Netherlands Mrs Kroon was also married to one M'Hallem Driss throughout the period of her relationship with Zerrouk, the father of her four children. The lack of attention of the European Court in Znamenskaya for any social factors regarding the link between the father and the child is unsatisfactory, as it ignores the quality of the relationship between the mother and alleged social father. This point is recognised by the three judges who dissented; in fact this is the very reason for their dissent. $^{241}$ So, returning to our three-pronged analysis (part 2.2.3 above), we suggest that there were some social factors in Znamenskaya, namely the cohabitation between the mother and alleged father, which were relevant to the claim. Finally, was there a conflict of interest? We suggest that on the facts it was actually rather risky to conclude that the mother and alleged father wanted the same thing, since the latter was dead and had at no stage indicated whether he considered himself linked to the child. However, the European Court considered this a case in which the interests of all three parties (two of whom were dead) pointed in the same direction, as it said:

'According to the Court's case-law, the situation where a legal presumption is allowed to prevail over biological and social reality, without regard to both established facts and the wishes of those concerned and without actually benefitting anyone, is not compatible, even having regard to the margin of appreciation left to the State, with the obligation to secure effective "respect" for private and family life (Kroon, cited above, $\S 40$ ). There has been therefore a violation of Article 8 of the Convention. ${ }^{242}$

\footnotetext{
${ }^{240}$ Znamenskaya v Russia, Eur. Ct. H.R. $12^{\text {th }}$ October 2005, § 12.

${ }^{241}$ Judges Rozakis, Botoucharova and Hajiyev.

${ }^{242}$ Znamenskaya v Russia, Eur. Ct. H.R. $12^{\text {th }}$ October 2005, § 31-32.
} 
The European Court invoked the 'biological and social reality' rule derived from the Kroon case again in the case of Shofman v Russia. Shofman was, by dint of the legal presumption of paternity, legal father of the child who had been born to his wife on $12^{\text {th }}$ May 1995. In September 1997 he learned that he was not the biological father of the child. Due to the inflexible time-limits applied in Russian law, the applicant was time-barred from challenging the presumption of paternity. The applicant complained that Article 8 ECHR had been violated. Applying the scheme used above in part. 2.2.3 to examine the Eureopan Court cases, there is in this case no biological link. There were social factors, namely the marriage between the applicant and his wife, and between September 1995 and March 1996 the applicant lived with his wife and son and, in the belief that he was his biological son, treated him as his child. The European Court, holding that Russian law violated Article 8 ECHR by time-barring the applicant's challenge to the presumption of paternity in such circumstances, invoked the 'biological and social reality' rule, arguing that the timebar was 'without regard to established facts and the wishes of those concerned." 243 One might question whether this was a good example of a case to apply that rule, as the interests of the applicant in challenging the presumption of paternity was not selfevidently compatible with the interests of the boy, who was still very young and definitely in need of financial support, in having a legal father. Nevertheless one can see that the European Court finds the 'biological and social reality' rule a magic formula which readily provides the Court with the space it needs to find that the national rule has transgressed the ECHR.

In Paulik v Slovakia, the facts of which were closely similar to those in Shofman $v$ Russia, concerning the applicant's inability to challenge the presumption of paternity due to time bars on the action, the European Court explored the nature of the conflict of interest between the applicant (man wishing to challenge the presumption) and his daughter. Again the European Court invoked the magic formula and said:

'As to the general interest, it is to be noted that the applicant's putative daughter is currently almost 40 years old, has her own family and is not

${ }^{243}$ Shofman v Russia, Eur. Ct H.R., $24^{\text {th }}$ February 2006, § 44. 
dependent on the applicant for maintenance (contrast with Yildirim, ${ }^{244}$ ). The general interest in protecting her rights at this stage has lost much of its importance compared to when she was a child. Furthermore, [the mother] initiated the DNA test and said that she had no objection to the applicant's disclaiming paternity. It therefore appears that the lack of a procedure for bringing the legal position into line with the biological reality flies in the face of the wishes of those concerned and does not in fact benefit anyone (see Kroon and Others v. the Netherlands, judgment of 27 October 1994, Series A no. 297 C, p. 58, § 40). ${ }^{245}$

\subsubsection{The significance of the European Court's attention for the presence or absence of a conflict of interest}

What does all this have to do with harmonisation? We have shown in the foregoing, beginning at part. 2.2.2, that three elements feature in the judgments by the European Court in questions regarding the establishment of a legal affiliation link between the father and child in cases of natural parenthood: biological link; social links and the presence or absence of a conflict of interest. We have furthermore shown that the last element often plays a decisive role in the European Court's decision. In other words, the absence of a conflict of interest between the mother, father and the child provides a significant reason for the European Court to lay down a limit to the law of parenthood which the national rule has transgressed. But when we reflect on the overview of the national rules governing the law of parenthood (in part I above and most particularly part. 1.3) we see that the situations in which there is no conflict of interest between the parties are not the difficult questions. Whereas in part 1.3 we have identified a considerable number of rules in which there is marked discrepancy between the rules of the legal systems studied, these rules govern situations which will frequently be marked by a conflict of interest. It thus seems that the European Court, which in its decisions regarding natural parenthood seems to be increasingly addicted to the 'social and biological reality' rule, is not busy with formulating new rules which might resolve new types of conflicts in the law of parenthood. Were the European Court to undertake such activity, this would put the member states under increasing pressure to bring their laws concerning parenthood closer together. In the light of the foregoing (part 2 of this article), the task of the European Court seems to

\footnotetext{
${ }^{244}$ Yildirim v. Austria, Eur. Court H.R. 19th October 1999.

${ }^{245}$ Paulik v. Slovakia, Eur. Ct. H.R. 10th October 2006.
} 
be rather more confined to identifying outdated, discriminatory rules which are of no benefit to anyone. In really ground-breaking conflicts of interest in cases such as Odièvre $v$ France, discussed above or Evans $v$ The United Kingdom ${ }^{246}$ the European Court can be criticised for backing off from determining the real conflict of interest which is at the heart of the issue.

\subsection{Assisted reproduction}

It has been noted earlier that there is a recognised distinction between determination of parenthood in cases of natural reproduction and in cases of assisted reproduction. We have noted in part. 2.1 that when one considers the rule-making activities of the Council of Europe this distinction is not watertight. However, the European Court does make a sharp distinction. In $X, Y$ and $Z v$ United Kingdom the European Court was called upon to decide whether Article 8 ECHR was violated by the lack of a possibility for $\mathrm{X}$ to be registered as the father of the four children who were born to his partner, Y. X was a female-to-male transsexual, who had made his transformation with the full blessing and support of the British National Health Service. Furthermore, the children had also been conceived using sperm donation provided by the very same National Health Service. It is therefore not surprising that, when the children, were born, the applicant was expecting to be able to establish in a formality that he was the children's legal father. Due to the law of the United Kingdom at that time, there was no possibility for $\mathrm{X}$ and $\mathrm{Y}$ to get married. Had $\mathrm{X}$ and $\mathrm{Y}$ been married, $\mathrm{X}$ would have experienced no difficulty establishing himself as the children's legal father, as he would have been presumed to be so by the presumption of legitimacy. Furthermore, had $\mathrm{X}$ not been a transsexual, he would have had the possibility, granted by the Human Fertilisation and Embryology Act, Section 27, to register himself, following conception by sperm donation with the full consent of both partners, as the children's legal father. None of this was possible for $\mathrm{X}$, who therefore brought his case to the European Court, relying on Article 8 ECHR and the rule in Johnston $v$ Ireland, Keegan v Ireland and Kroon v The Netherlands, cited in part 2.2.2.3 above, according to which the legal system should make it possible at the date of birth or as soon as possible thereafter, to establish the legal affiliation link between the father and child. Holding that Article 8 ECHR did not protect the applicant's claim to be registered as the legal father of his children, the Court said:

${ }^{246}$ Evans v United Kingdom, Eur. Ct. H.R. $7^{\text {th }}$ March 2006. 
'It is true that the Court has held in the past that where the existence of a family tie with a child has been established, the State must act in a manner calculated to enable that tie to be developed and legal safeguards must be established that render possible, from the moment of birth or as soon as practicable thereafter, the child's integration in his family (see for example the above-mentioned Marckx judgment, p. 15, para. 31; the Johnston and Others v. Ireland judgment of 18 December 1986, Series A no. 112, p. 29, para. 72; the above-mentioned Keegan judgment, p. 19, para. 50; and the abovementioned Kroon and Others judgment, p. 56, para. 32). However, hitherto in this context it has been called upon to consider only family ties existing between biological parents and their offspring. The present case raises different issues, since $\mathrm{Z}$ was conceived by AID and is not related, in the biological sense, to $\mathrm{X}$, who is a transsexual. ${ }^{247}$

As there was no common ground between the member states regarding the law applicable to the parenthood of transsexuals, the European Court saw no reason to find that Article 8 ECHR had been violated. ${ }^{248}$ It is to be hoped that the law in this regard has been changed by the creative decisions in Goodwin and I. $v$ United Kingdom, ${ }^{249}$ on the question of civil status and the right to marry of transsexuals. However an examination of that question would go outside the scope of this essay, which is to examine the role of the European Court in bringing about harmonisation in the law of parenthood.

\subsection{Assisted reproduction: the criteria}

It remains to apply our analytical scheme (the three-pronged criteria explained in part. 2.2.3) to the $X, Y$ and $Z$ case. In that case there was no biological link between the applicant and his children, however the European Court acknowledged there were sufficient social factors to enable the relationship between him, his partner and their four children to qualify for protection as 'family life'. ${ }^{250}$ There was also no conflict of interest; all the parties wanted the same thing. However, the European Court

\footnotetext{
${ }^{247} X, Y$ and $Z v$ United Kingdom, $22^{\text {nd }}$ April 1997, $\S 43$.

${ }^{248} X, Y$ and $Z v$ United Kingdom, $22^{\text {nd }}$ April 1997, $\S 44-45$.

${ }^{249}$ Goodwin v United Kingdom, I. v United Kingdom, 11 th July 2002.

${ }^{250} X, Y$ and $Z v$ United Kingdom, $22^{\text {nd }}$ April 1997, $\S 36-37$.
} 
introduced a new factor which seems inextricably linked to the newness of the claim and its character as concerning assisted reproduction; namely, there was no common ground.

\section{Convergence or divergence?}

We started with the assumption that in order to determine the harmonising effect of the case law of the European Court, one first has to determine how legal systems differ. After that, one has to analyse to what extent the case law of the European Court allows for the differences between the legal systems. So far, we have analysed these two aspects separately.

In the first part we have presented a model which systematically shows the differences between the laws on affiliation. ${ }^{251}$ The model allows us to differentiate the grounds for legal affiliation and the 'secondary principles' on the basis of which a deviation from the basic principle is allowed. So for example, we have seen that genetic affiliation is the ground for legal paternity in case of natural reproduction in all the legal systems under consideration. However, some legal systems like the Dutch, the French and the German legal system allow for exceptions to this basic principle on the basis of secondary principles such as legal certainty and the protection of the private life of the members of the legal family.

The first conclusion which follows from the analysis of the national legal systems in the first part is that legal systems differ most profoundly from one another at the most elementary level of the model: the grounds for legal affiliation. It has been shown that legal maternity can be based either on apparent status or on the fact of giving birth. In case of legal paternity, the basis is either genetic paternity, apparent status or intention. It has been shown that legal systems do not only differ as to which grounds they use, but also as to the demarcation of the grounds: intention as a ground for legal parenthood under French law works differently compared to intention as a ground for legal paternity under English or Swedish law. ${ }^{252}$

The second conclusion is that, although legal systems share the same secondary principles, these principles have been worked out differently. This is evidenced by the different rules on periods of limitation, locus standi and the function of apparent status. The most important interests which are put forward to allow a

\footnotetext{
${ }^{251}$ Par. 1.1 A model for the comparison on national laws on legal affiliation.

${ }^{252}$ Par. 1.2. Grounds for legal affiliation.
} 
deviation from the ground for legal affiliation are legal certainty and the stability of the child's legal affiliation status and the protection of the private life of the members of the legal family. ${ }^{253}$

In the second part we analysed the case law of the European Court in matters of legal parenthood. This analysis allows for two conclusions. In the first place, it has been shown by the Court's decision in $X, Y$ and $Z v$. United Kingdom that its approach towards family life and legal parenthood depends on whether the case is about natural reproduction or artificial insemination. From a national perspective, such a differentiation gives no reason for surprise, because national legal systems do the same.

The second conclusion is however more revealing. It appeared that unlike in case of national legal systems, it is hard to derive a basis for legal affiliation from the Court's case law. We have observed that when one considers the three criteria used by the European Court to determine whether a man has family life with a child which should be respected by the State, i.e. biological link, social relationship or the presence of a conflict of interest between the parties, that the last feature often plays a decisive role in the European Court's decision. ${ }^{254}$

A conflict of interest between the mother, father and child (in any combination of conflict of interest) forms a reason for the European Court not to intervene and to allow the State concerned a wide margin of appreciation to resolve the conflict of interest. This means that national systems are not, in the cases where there is a really difficult conflict to resolve, being pinned down by the European Court to comply with a minimum norm under Article 8 ECHR. We suggest that the European Court is rather more confining its task to smoothing things over in cases where the rules have already been established. A classical example is the case of Marckx v Belgium, in fact, where the judgment was founded upon an existing treaty obligation (with which, it must be agreed, not all states were in compliance). The fact that the European Court sometimes gets in a muddle with its ideas about a conflict of interest, as happened in Znamenskaya $v$ Russia, does not, in our view, change the basic picture. In fact, in the overall picture, we suggest that the role of the European Court is much less adventurous in relation to natural parenthood than, at first blush, might be expected, on the basis of the volume of case law, for example.

\footnotetext{
${ }^{253}$ Par. 1.3. Establishment and annulment of legal parenthood.

${ }^{254}$ Par. 2.2. Natural reproduction and legal parenthood.
} 
The absence of a basis for legal parenthood is even more apparent in case of artificial reproduction. ${ }^{255}$ Very explicitly, the European Court has made it clear in $X, Y$ and $Z v$ United Kingdom that it does not consider that it has a harmonising role to play.

If we combine the conclusions of the first and the second part, it follows that it is hard to apply the model we used to analyse the national legal systems to the case law of the European Court in matters concerning legal parenthood. Although, one could argue that in case of natural reproduction the basis for legal paternity is biological affiliation in combination with social factors (first layer of the model), it is not clear at all what the exceptions to this basis are (second layer of the model). It only follows from our analysis in the second part that in case of a conflict of interest the State has a wide margin of appreciation to solve that conflict of interest, but the Court gives no guidance as to how that conflict of interest should be solved. Moreover, in case of legal maternity and in case of legal parenthood following artificial reproduction the ground for legal affiliation is lacking completely.

What does this tell us about the harmonising effect of the Court's case law? Our analysis shows that the harmonising effect should not be overestimated. Apparently, the Court does not perceive its function as being the setting of Europewide standards for legal parenthood. The Court and its case law function as a complementary system next to national legal systems, to correct certain results following from the rigid application of national law on legal affiliation. In performing its corrective role in the field of legal parenthood the European Court, apparently, is lead by principles which are determined by the Member States and not vice versa.

${ }^{255}$ Par. 2.4. Assisted reproduction: the criteria. 


\section{The Maastricht Faculty of Law Working Paper series:}

2006/11 Anke Dahrendorf, 'Trade meets Culture. The Legal Relationship between WTO rules and the UNESCO Convention on the Protection and Promotion of the Diversity of Cultural Expressions'

2006/10 Peter Van den Bossche, 'NGO Involvement in the WTO. A lawyer's perspective on a glass half-full or half-empty'

2006/9 Maria Zettel, 'The GATS, Privatization and Water Services. An Overview of Legal Aspects'

2006/8 Jan M. Smits, 'Private law and fundamental rights: a sceptical view'

2006/7 Bob Brouwer \& Jaap Hage, 'Basic Concepts of European Private Law'

2006/6 Conrad J.P. Van Laer, 'Is the employed scholar free not to publish? Limitations of disclosure rights in a comparative perspective'

2006/5 Peter Van den Bossche, 'Confusion and Concern with regard to SACU Dispute Settlement. Some observations on Article 13 of the SACU Agreement'

2006/4 Mariolina Eliantonio, 'The enforcement of EC rights against national authorities and the influence of Köbler and Kühne \& Heitz on Italian administrative law: opening Pandora's box?'

2006/3 Jan Smits, 'European Private Law: A Plea for a Spontaneous Legal Order'

2006/2 Geerte Hesen, 'A comparative perspective of the liberalisation of the gas market and the effects on welfare: Belgium, Germany and the Netherlands'

2006/1 Peter Van den Bossche, 'Radical Overhaul or Pragmatic Change? The Need and Scope for Reform of Decision-Making in the World Trade Organization'

2005/10 Peter Van den Bossche, 'Rules on NGO Accreditation. Do Existing Legal Arrangements Facilitate the Legitimization of the Role of NGOs in International Organizations?'

2005/9 Jan Smits, 'Diversity of Contract Law and the European Internal Market'

2005/8 Stefaan Van den Bogaert \& An Vermeersch, 'Sport and the European Treaty: A Tale of Uneasy Bedfellows?'

2005/7 Ellen Vos, 'Regional Integration through Dispute Settlement: The European Union Experience’

2005/6 Peter Van den Bossche, Denise Prévost \& Mariëlle Matthee, 'WTO Rules on Technical Barriers to Trade' 
2005/5 John Hagedoorn and Geerte Hesen, 'The Governance of Inter-Firm Technology Partnerships and Contract Law - An Analysis of Different Modes of Partnering and their Contractual Setting'

2005/4 Michael Faure, 'Economic Criteria for Compulsory Insurance'

2005/3 Iveta Alexovičová \& Peter Van den Bossche, 'Effective Global Economic Governance by the World Trade Organization'

2005/2 Michael Faure \& Wang Hui, 'Economic Analysis of Compensation for Oil Pollution Damage'

2005/1 Peter Van den Bossche, 'From Afterthought to Centerpiece: The WTO Appellate Body and its Rise to Prominence in the World Trading System'

All papers are available for download at

http://www.rechten.unimaas.nl/maastrichtworkingpapers 